\title{
Structural Overview and Morphotectonic Evolution of a Strike-Slip Fault in the Zone of North Almora Thrust, Central Kumaun Himalaya, India
}

\author{
Lalit M. Joshi, ${ }^{1}$ Pitamber D. Pant, ${ }^{1}$ Bahadur S. Kotlia, ${ }^{1}$ Girish C. Kothyari, ${ }^{2}$ \\ Khayingshing Luirei, ${ }^{3}$ and Anoop K. Singh ${ }^{1}$ \\ ${ }^{1}$ Centre of Advanced Study in Geology, Kumaun University, Nainital 263002, India \\ ${ }^{2}$ Institute of Seismological Research, Raisan, Gandhinagar, Gujarat 382009, India \\ ${ }^{3}$ Wadia Institute of Himalayan Geology, Dehradun 248001, India \\ Correspondence should be addressed to Lalit M. Joshi; joshilalit81@gmail.com
}

Received 3 July 2015; Revised 28 December 2015; Accepted 31 December 2015

Academic Editor: Karoly Nemeth

Copyright ( $\odot 2016$ Lalit M. Joshi et al. This is an open access article distributed under the Creative Commons Attribution License, which permits unrestricted use, distribution, and reproduction in any medium, provided the original work is properly cited.

\begin{abstract}
The aim of the present research is to provide the base line details of the NNW-SSE trending Raintoli fault (RF) which is running parallel to the North Almora Thrust (NAT) along the Saryu valley from Seraghat-Naichun to Seri in the central sector of the Uttarakhand Himalaya, India. The RF is characterized as dextral strike slip fault and behaves as a ductile shear zone within the zone of NAT. The dextral sense of shear movement of RF is delineated by the fabric of the shear zone rocks including microscopically observed indicators such as sigma and delta porphyroclasts, quartz $c$-axis, and the field structural data. Additionally, in the quaternary period the dextral strike slip fault is reactivated with oblique slip component as characterized by various geomorphic indicators, for example, triangular facets, abandoned river channels, unpaired fluvial terraces, and V-shaped valleys with recurrent seismicity. Further, the morphometric parameters including Valley Floor Width to Valley Height $\left(V_{f}\right)$, asymmetry factor (AF), and gradient index (GI) further prove active nature of RF as suggested by low values of hypsometric integration, V-shaped valley, higher gradient index, and tilting of Saryu basin.
\end{abstract}

\section{Introduction}

The Himalaya has been divided into four lithotectonic subdivision from south to north, for example, Siwalik or SubHimalaya, Lesser Himalaya, Higher Himalaya, and Tethys Himalaya [1]. The intracrustal boundary thrusts, for example, Himalayan Frontal Thrust (HFT), Main Boundary Thrust (MBT), Main Central Thrust (MCT), and Trans Himadri Fault (THF), have been separating the lithotectonic unit from south to north, respectively (Figure 1(a)). Further, the Lesser (Central) Kumaun Himalaya, stretching from Nepal to Himachal Pradesh, is characterized by allochthons nappes (Thrust sheets), for example, Almora nappe, Ramgarh nappe, and Krol nappe, and tectonic windows within which the Precambrian-Cambrian autochthons are exposed $[1,2]$. The Almora nappe is a consequence of tectonic transport of the rocks of Higher Himalayan Metamorphic Belt to the Lesser Himalaya over the Main Central Thrust (MCT) during Eocene-Oligocene [3, 4]. The Almora nappe is the largest of the Klippe/nappes distributed along the Himalayan arc [5]. The northern and southern flanks of Almora nappe were described as the North Almora Thrust (NAT) and South Almora Thrust (SAT), respectively [2]. The southern limb is thicker and gently dipping about $20^{\circ}-30^{\circ}$ toward $\mathrm{NNE} / \mathrm{NE}$ direction, whereas the northern limb is thinner and steeply inclined, for example, $45^{\circ}-75^{\circ} \mathrm{SSW} / \mathrm{SW}$ [6]. Further, a large scale shear zone of the NAT is characterized by the presence of the mylonitic sequence [7-9]. Moreover, the Lesser Himalaya is characterized by the tear faults and fracture zones are oriented predominantly NW/NNW-SE/SSE direction [10]. Thus, the thrust bounded synclinal nappes and the subsidiary thrusts/faults have been reactivated in the 
$70^{\circ} \mathrm{E}$

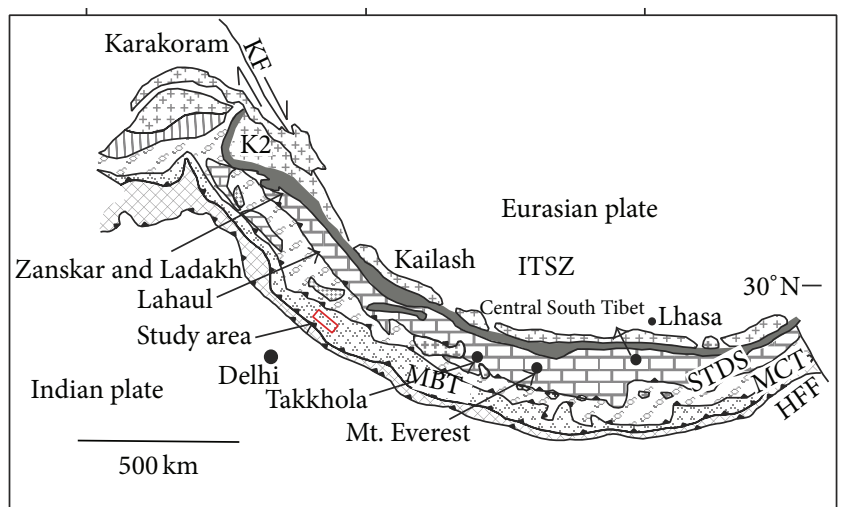

Siwalik molasse

ITSZ and related sequence

IIIII Kohistan island arc

臣 Tethyan sediments

F+⿴囗十 Miocene leucogranites

Higher Himalayan crystallines

Lesser Himalayan sedimentaries

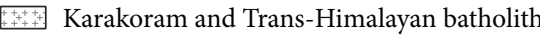

(a)

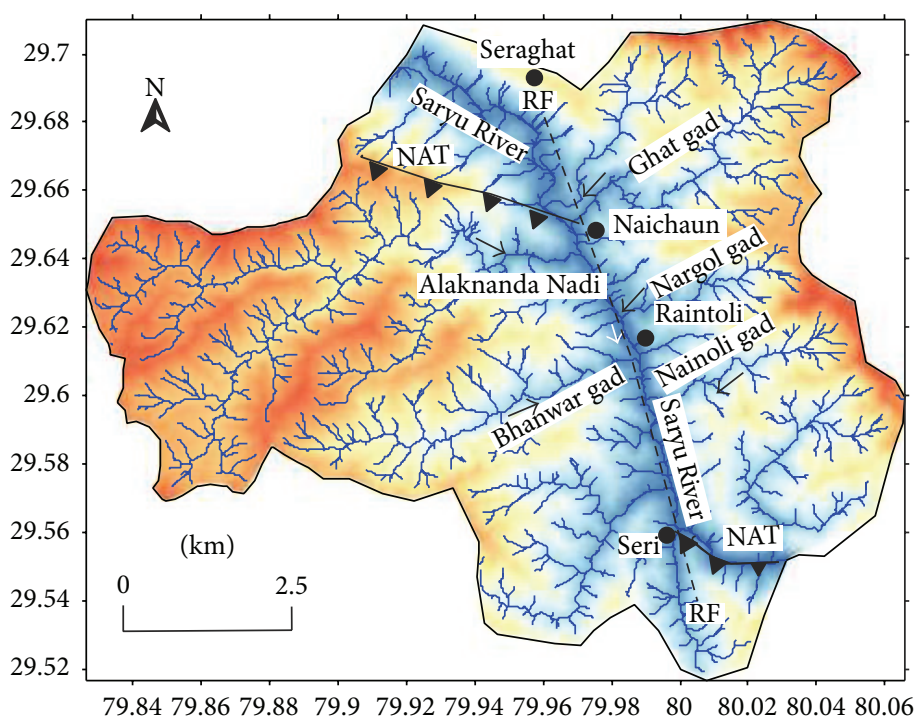

(c)

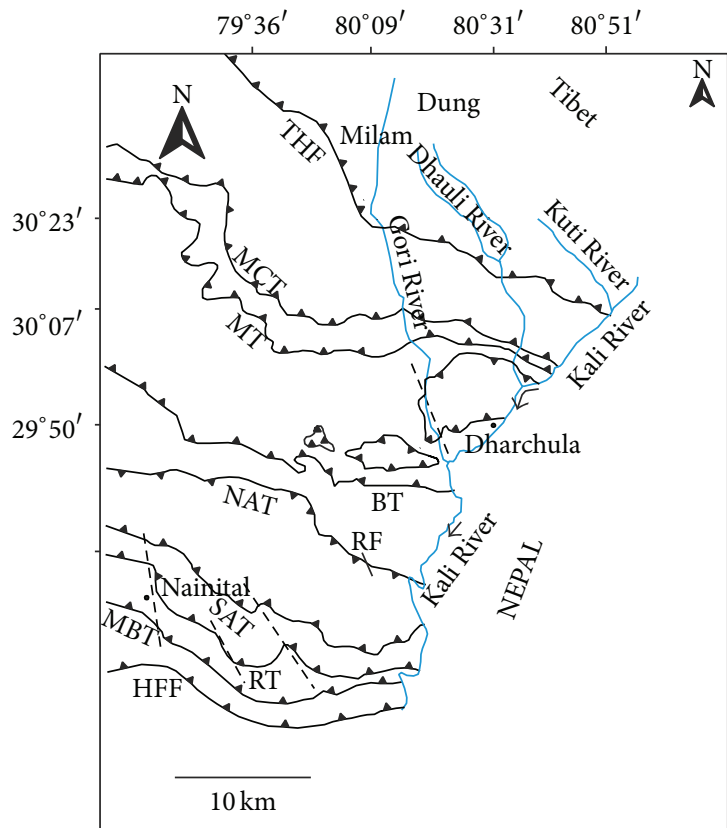

HFF Himalayan frontal fault MBT Main Boundary Thrust

RT Ramgarh Thrust

SAT South Almora Thrust

NAT North Almora Thrust

BT Berinag Thrust
MT Munsiyari Thrust MCT Main Central Thrust THF Trans Himadri Fault KVT Kali valley transect GVT Gori valley transect

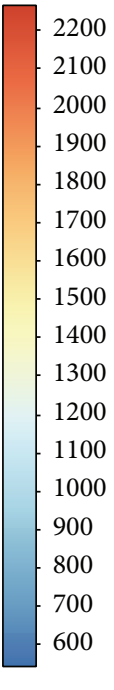

FIGURE 1: (a) Lithotectonic units of the Himalayan orogenic belt [20]; (b) tectonic set-up through the Kumaun Himalaya showing major tectonic boundaries with the location of RF along the zone NAT [20, 21]; (c) drainage map of the studied sector of the Saryu River with delineation of RF. 
TABLE 1: Lithotectonic succession of the inner and outer Kumaun Lesser Himalaya [21].

\begin{tabular}{|c|c|c|c|c|}
\hline \multicolumn{3}{|c|}{ Outer Lesser Himalaya } & \multicolumn{2}{|c|}{ Inner Lesser Himalaya } \\
\hline Almora nappe & Almora Group & $\begin{array}{c}\text { Gumalikhet Formation } \\
\text { Champawat Granitoid } \\
\text { Saryu Formation }\end{array}$ & \multicolumn{2}{|c|}{ Munsiyari Formation } \\
\hline \multicolumn{3}{|c|}{ South Almora Thrust } & \multicolumn{2}{|c|}{ Munsiyari Thrust } \\
\hline \multirow[t]{2}{*}{ Ramgarh nappe } & Ramgarh Group & $\begin{array}{l}\text { Debguru Porphyroid } \\
\text { Nathuakhan Formation }\end{array}$ & \multicolumn{2}{|c|}{ Barkot and Bhatwari units } \\
\hline & \multicolumn{2}{|c|}{ Ramgarh Thrust } & \multicolumn{2}{|c|}{ Barkot-Bhatwari Thrust } \\
\hline Krol nappe & Mussoorie Group & $\begin{array}{c}\text { Tal Formation } \\
\text { Krol Formation } \\
\text { Blaini Formation } \\
\text { Nagthat Formation } \\
\text { Chandpur Formation } \\
\text { Mandhali Formation } \\
\end{array}$ & \multicolumn{2}{|c|}{ Berinag Formation } \\
\hline \multicolumn{3}{|c|}{ Krol Thrust (Main Boundary Thrust) } & \multicolumn{2}{|c|}{ Berinag Thrust } \\
\hline \multirow{2}{*}{ Allochthon } & \multirow{2}{*}{ Damtha Group } & \multirow{2}{*}{$\begin{array}{l}\text { Rautgara Formation } \\
\text { Chakrata Formation }\end{array}$} & Tejam Group & $\begin{array}{c}\text { Mandhali Formation } \\
\text { Deoban Formation }\end{array}$ \\
\hline & & & Damtha Group & $\begin{array}{l}\text { Rautgara Formation } \\
\text { Chakrata Formation }\end{array}$ \\
\hline
\end{tabular}

recent past resulting in landscape rejuvenation as evidenced by incised meandering, deep gorges with convex walls, displacement and tilting of terraces as well as damming of ancient drainage, and formation of paleolakes [11-19]. In addition, the seismotectonic activity throughout the Central Himalaya is also evident by the occurrence of moderate to large magnitude earthquakes in recent past, for example, Kangra (1905), Kinnaur (1975), Dharamshala (1978, 1986), Uttarkashi (1991), and Chamoli (1999).

The study area stretches from Seraghat to Seri $\left(70^{\circ} 55-\right.$ $80^{\circ} 05 \mathrm{E}$ and $29^{\circ} 35-29^{\circ} 45 \mathrm{~N}$; Survey of India toposheet No. $53 \mathrm{O} / 14$ ) in the zone of Almora nappe (Figure 1(b)). Presently investigated fault, for example, Raintoli Fault (RF) coincides with the NAT for $20 \mathrm{~km}$ from Seri to Naichun, which passes through Naichun, Raintoli, and Seri (Figure 1(c)). Along this segment, the RF $[10,21]$ or Saryu River Fault (SRF, [22, 23]) behaves as a dextral strike-slip fault. In the present study, we prefer to describe the fault as Raintoli Fault (RF) and our aim is (1) to determine the sense of movement and provide the structural overview of the RF using the field observations, kinematic and quartz C-fabric, and (2) quaternary reactivation of RF within the zone of NAT using geomorphotectonic data sets.

\section{Geological Setting}

The Lesser Himalaya Sequence (LHS) in the Kumaun Himalaya is further divided into the inner (older) Lesser Himalaya and outer (younger) Lesser Himalaya [3, 4, 21, 24, 25] (Table 1). At the base of Lesser Himalaya, the rock of Damtha Group comprises the Chakrata and Rautgara Formation. The Damtha Group was conformably succeeded by the Tejam, Jaunsar, Mussoorie, Ramgarh, and Almora Groups of rock (Table 1). The different Groups further consist of various formations (see Table 1). The study made up with the rocks of Almora crystallines consists of the mylonitized quartz porphyry of the Saryu Formation of Almora Group, which overlay coarse grained arenites and calcareous slates of the Rautgara Formation of Damtha Group with a tectonic contact, that is, the NAT and the Precambrian metasedimentaries of Deoban Formations of Tejam Group [1, 2, 21]; see Figure 2(a). The tectonic history of Almora nappe is characterized by three distinguishable structural regimes, for example, preshear zone structures, syn-shear zone structures, and postshear zone structures with respect to the basal shear zone of the Almora nappe [9]. Along the NAT, a zone of mylonitic rocks is developed due to strain localization during the tectonic emplacement of the Almora nappe over the Lesser Himalayan sequence [26].

\section{Methodology}

The structural overview of the area is based on the detailed field observations, petrofabric and quartz $c$-axis analysis using the oriented samples (parallel to dip section), representing the $X Z$ plane of finite strain ellipsoid (with $X \geq$ $Y \geq Z$ axes). The microstructural analysis was carried out under the optical microscope and shear sense indicators were used to detect the sense of shear [27-30]. The Lattice Preferred Orientation (LPO) was analyzed after Passchier and Trouw [31], Turner and Weiss [32], and Kutty and Joy [33]. A minimum of 300 grains were measured in each sample. As the optic (001) $c$-axis in quartz grains can be measured and plotted easily, the quartz grains were studied in detail. For fabric diagrams, the oriented thin sections, mounted on a universal stage, were studied. The stereographic plots were created following Kutty and Joy [33].

The geomorphic observations were based on the extensive field surveys and various morphometric parameters using Advanced Spaceborne Thermal Emission and Reflection Radiometer (ASTER) image with $30 \mathrm{~m}$ resolution and geographical toposheets at 1:50,000 scale. The morphometric 


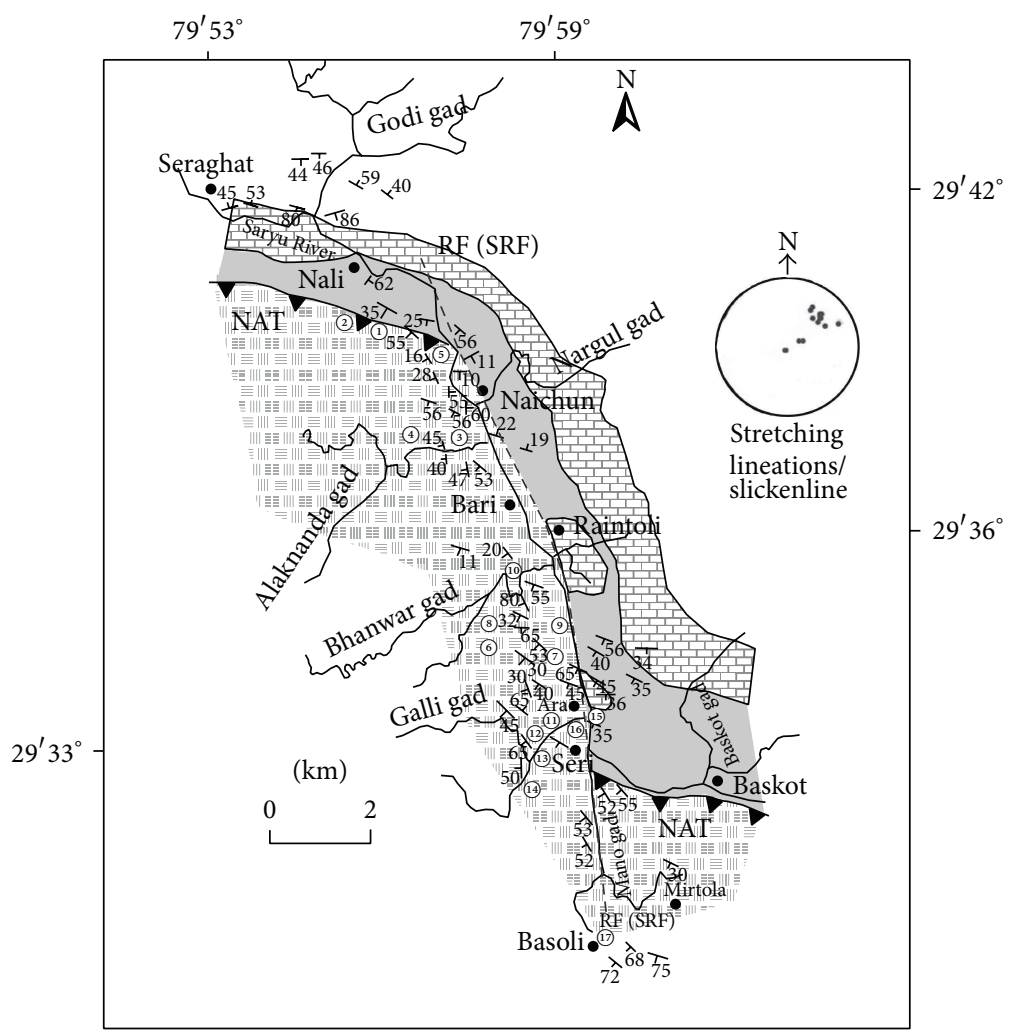

Deoban Formation

Rautgara Formation

Almora crystallines

(a)

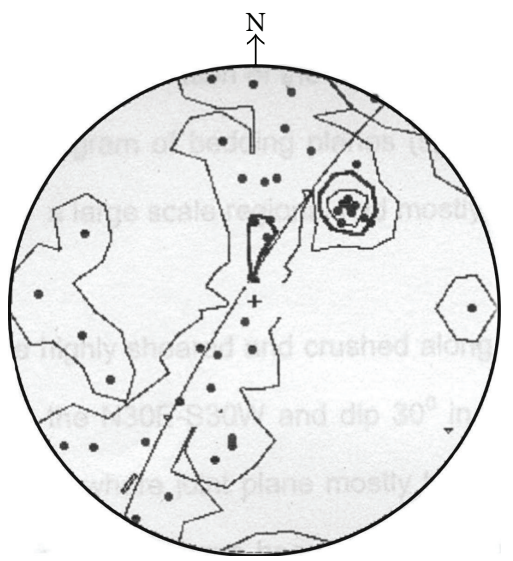

No. of records: 48 Max. density $=10$ Min. density $=0$

Contour levels Eigenvalues 7 vectors 0.54: 1.0, 25.3, 46.5

$0.35: 1.0,218.3,42.7$ $0.11: 1.0,122.3,6.8$
NAT: North Almora Thrust

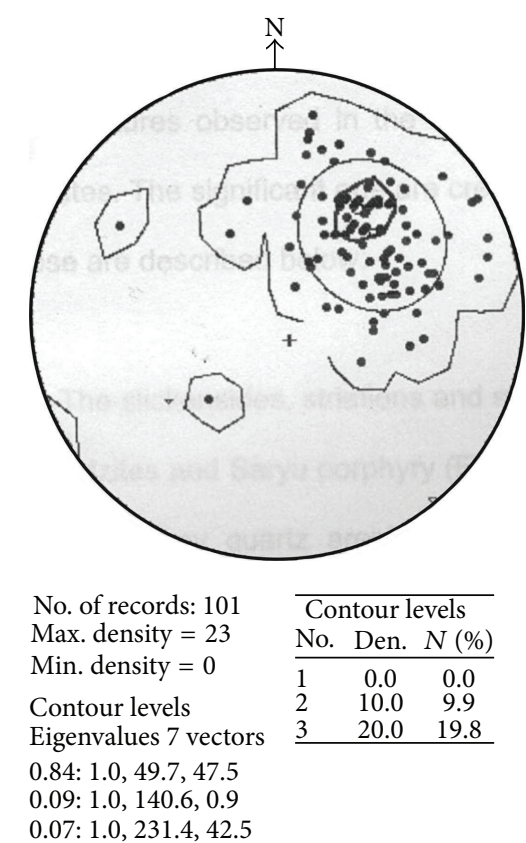

(c)

Figure 2: (a) Geological and structural map of the study area [21] and the encircled numbers are samples location for kinematic and quartz $c$-axis analysis, with the orientation of stretching lineations in upper right hand corner of the map. (b) $S_{o}$ in metasedimentaries (Rautgara and Deoban Formations). (c) $S_{1}$ surface in Almora crystallines. 
parameters such as CL (channel length), VL (valley length), and $\mathrm{AL}$ (shortest air distance between source and mouth of the river) were measured from Survey of India toposheet (1:50,000 scale). Further, the Channel Index (CI), Valley Index (VI), Hydraulic Sinuosity Index (HSI), Topographic Sinuosity Index (TSI), and Standard Sinuosity Index (SSI) were calculated using the formula as given by Muller's [34]; for example, $\mathrm{CI}=\mathrm{CL} / \mathrm{AL}$; VI $=\mathrm{VL} / \mathrm{AL}$; $\mathrm{SSI}=\mathrm{CI} / \mathrm{VI}$; $\mathrm{HSI}=\%$ equivalent of $(\mathrm{CI}-\mathrm{VI}) /(\mathrm{CI}-1)$; and $\mathrm{TSI}=\%$ equivalent of $(\mathrm{VI}-1) /(\mathrm{CI}-1)$.

To understand the tectonic tilting and basin asymmetry, the asymmetry factor (AF) was calculated using the formula given by Keller and Pinter [35], which is defined as AF = $100\left(A_{r} / A_{t}\right)$, where $A_{r}$ is the area of the basin to the right (facing downstream) of the trunk stream and $A_{t}$ is the total area of the drainage basin. The value below and above 50 may suggest tilting [35]. The tilting of the basin is also verified by topographic symmetry factor $(T)$ which is defined as $T=$ $\mathrm{Da} / \mathrm{Dd}$, where $\mathrm{Da}$ is distance from the midline of the drainage basin to the midline of the active channel and Dd is distance from the basin midline to the basin divide. It is assumed that $T=0$ when the basin is perfectly symmetric and the value greater than 0 indicates the migration of stream channels which may be an indication of possible ground tilting in a direction [36].

For differential uplift of the river basin, the value of stream length gradient index (GI) was calculated with the help of the longitudinal valley profile using the formula given by Rhea [37], for example, GI $=\left(h_{1}-h_{2}\right) / \ln l_{2}-$ $\ln l_{1}$, where $h$ is elevation and $l$ is distance. Additionally, the hypsometric curve, generated by Microdem using ASTER GDEM image and hypsometric integral (HI), was prepared using the formula $\mathrm{HI}=H_{\text {mean }}-H_{\min } / H_{\max }-H_{\min }$, where $H_{\text {mean }}, H_{\text {max }}$, and $H_{\text {min }}$ are the mean, maximum, and minimum elevation, respectively. The ratio of Valley Floor Width to Valley Height $\left(V_{f}\right)$ was calculated using the formula $\left(V_{f}\right)=2 V_{\mathrm{fw}} /\left[\left(E_{\mathrm{ld}}-E_{\mathrm{sc}}\right)+\left(E_{\mathrm{rd}}-E_{\mathrm{sc}}\right)\right]$, as given by Keller and Pinter [35], where $V_{\mathrm{fw}}$, is width of the valley floor, $E_{\mathrm{ld}}$ and $E_{\mathrm{rd}}$ are elevations of left and right valley divides, and $E_{\mathrm{sc}}$ is elevation of the valley floor.

\section{Structural Overview}

4.1. Structural Set-Up of the Area. The NNW-SSE trending fault mainly Raintoli Fault coincides or is roughly parallel to the NAT [21,26], which has formed as a consequence of severe tightening of folds of the autochthon [6]. The rocks along the NAT and the RF are almost crushed or recrystallized as observed along the Saryu valley from the Naichun to Seri section. Further, the mylonitic rocks have developed due to strain localization along NAT [26]. The mylonites are fine to medium grained, highly compact, and streaky banded in nature. These rocks are found in the wide zone of NAT and NNW-SSE trending RF, formed as a result of recrystallization of mineral grains of granite and quartzite under ductile deformation. The rocks in the zone of NAT and RF are characterized by various structural features, for example, bedding surface $\left(S_{o}\right)$, cleavage $\left(S_{1}\right)$, and schistosity $\left(S_{2}\right)$, boudinage, mineral lineations, slickenlines, and the folds with almost vertical axial planes (inverted tight to isoclinal). The bedding $\left(S_{o}\right)$ is prominent in the Rautgara and Deoban Formations, in which the S-pole diagrams of $S_{o}$ show a large scale regional folding with NW-SE trending axis (Figure 2(b)). Highly deformed quartzite shows significant bedding plane, dipping $40^{\circ}$ to $60^{\circ}$ towards SW at Naichun (see Figure 2(a)). The mylonites are highly sheared, with shear planes dipping towards $\mathrm{N} 30^{\circ} \mathrm{E}-\mathrm{S} 30^{\circ} \mathrm{W}$. The S-pole diagram of foliation has a mean cleavage plane dipping towards SW direction (Figure 2(c)). The C-S fabrics were developed in the mylonite and rocks of Rautgara Formation perhaps dipping towards SW direction and suggesting the downdip movement (Figure 3(a)). Further, the slickenlines in mylonites, quartz arenites, and slates of Rautgara Formation mostly trend in SW direction (Figure 3(b)). The slickenlines developed on $S_{1}$ surface of mylonitized granite gneiss near the Ara, trending $52^{\circ}$ towards the SW (Figure 2). The $S_{1}$ surfaces of mylonitic granite gneiss trending towards SW are developed parallel to the extension direction. The crenulation lineations are well developed in mylonites, plunging $40^{\circ}-$ $55^{\circ}$ towards NW. The tight to isoclinal folds with vertical axial planes are observed. Drag folds were also observed mainly in the mylonites and phyllite showing axial planes convergence beyond $45^{\circ}$ in SW direction along the shear planes (Figure 3(c)). These types of folds are possibly formed due to fault propagation or may also develop as a result of frictional drag and differential compaction into monoclinal warps present at the fault tips [38]. The rotated boudins in the Rautgara rocks are well developed along the Mano gad (gad $=$ stream) at Seri (Figure 3(b)) and these may have originally been developed as continuous rigid (competent) band between relatively less competent layers and folded along the shear plane.

4.2. Microscopic Observations. The rocks of the Saryu Formation appear to be highly sheared and recrystallized with stretching of mica minerals and development of quartz porphyroblasts (Figure 4(a)). Under petrographic analysis, recrystallization of rocks was also observed by broken fragments and matrix of ultramicroscopic grains (Figure 4(b)). The rocks of Deoban Formation shows comparatively coarser twinned dolomitic calcite with at least one set of cleavage (Figure 4(c)). The metalimestone shows the kink bands (Figure 4(d)). The quartzite and slates generally form fine grained clusters of highly recrystallized quartz which occur as ribbon. The recrystallization may have resulted from progressive rotation of subgrains and grains boundary migration (Figure 4(e)). The crystallized quartz also shows sharp boundaries (Figure 4(f)). The feldspar porphyroblasts are surrounded by muscovite and biotite flakes, in which the internal and external schistosity indicate predeformational history of the rock. Most quartz porphyroclasts are composed of fine recrystallized material formed by the recrystallization from the rim of the porphyroclasts, suggesting that the rate of recrystallization was increased with the intensity of deformation [39].

4.3. Kinematics. The kinematics of crustal scale shear zones plays a role in the reconstruction of tectonic evolution of 


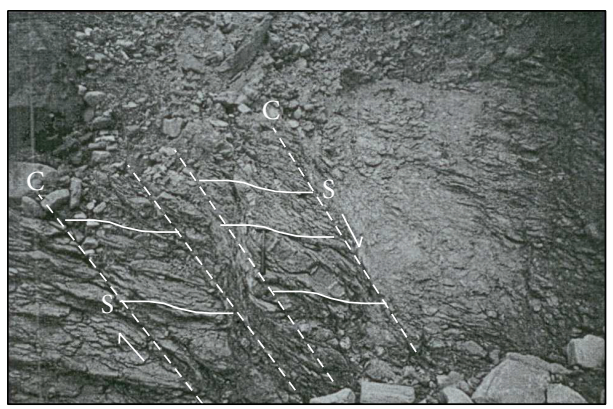

(a)

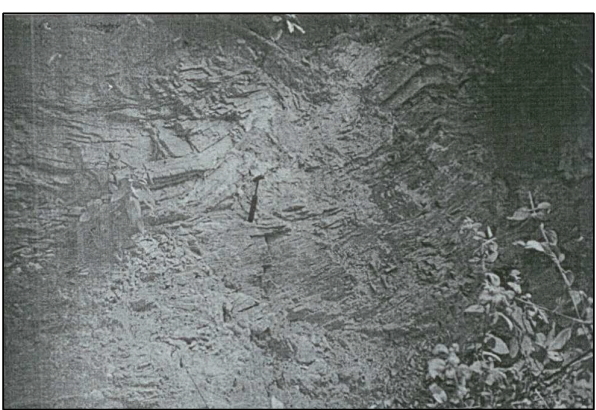

(c)

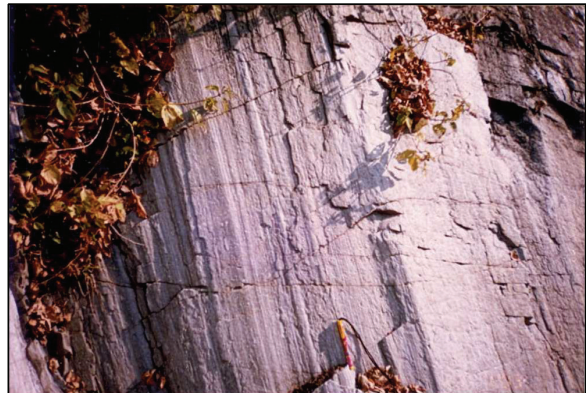

(b)

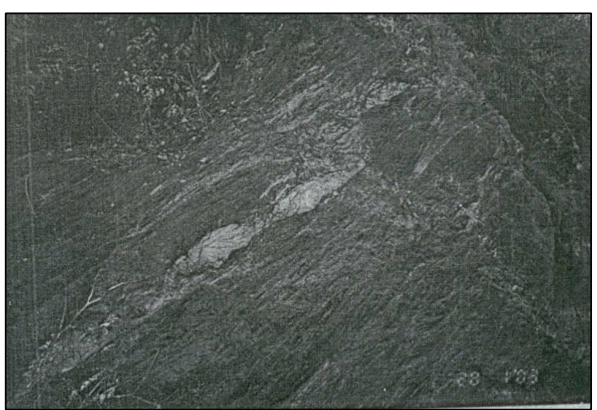

(d)

Figure 3: (a) C-S structure in Rautgara Formation; (b) stretching lineations in Rautgara quartzite; (c) drag folding in the Rautgara rocks with $\mathrm{S}$ to SW movement; (d) asymmetrical folded boudinage in mylonite rocks.

the orogenic systems $[8,40-45]$. The shape of the deformed trails on some mantle porphyroblasts have been used as shear sense indicators $[31,46]$. In this study, 11 (out of 17 oriented samples) $X Z$ sections were prepared parallel to the stretching lineation (dip direction) for Quartz $c$-axis fabric and kinematic study. Significant kinematic structures, mainly mantle porphyroblasts in mylonites (e.g., sigma and delta types) with occasional microfaulting, seems to be important fabric elements [47].

The delta type structures are formed when the rate of rotation becomes higher than the rate of dynamic recrystallization [31] and have monoclinic shape symmetry, which is developed by the breakdown of porphyroclasts due to rotation in the process of deformation (Figure $4(\mathrm{~g})$ ). These structures show SW movement of the shear zone along the NAT and RF.

The sigma type porphyroblasts are formed when the rate of dynamic recrystallization is higher than the rate of shear strain [31]. In such structures, the median line does not cross the schistosity trend or reference line and rotation rate is also lower and therefore is frequently found in samples (see Figure 4(h)). Additionally, the microfracturing was also observed in feldspar porphyroclasts.

\subsection{Lattice Preferred Orientation (LPO) of Quartz c-Axis} Fabric. The fabric study of grains, particularly LPO of quartz grains, provides valuable information on fabric pattern under different strain conditions and on the kinematic of flow [31, 48-52]. The RF shows the central girdle as asymmetrical or monoclinic in all cases, indicating a noncoaxial deformation or rotational strain (Figure 5). The stereo plots of quartz $c$ axis for various samples indicate the type- 1 crossed girdle fabric distribution and represent the $c$-axis maxima near the periphery of the net [39]. The pattern of $c$-axis fabric also shows marked asymmetry with respect to tectonic deformation, most commonly of rotational type [53-55]. The fabric diagrams of our samples show an asymmetrical or monoclinic fabric and asymmetry of girdles, suggesting the dextral or down-dip movement from top to south in all cases (see Figure 5).

\section{Landscape Characteristics of RF}

5.1. Field Observations of Geomorphic Activities. The tectonic rejuvenation along the NAT was suggested not only by number of geomorphic features, for example, abandoned channels, tilted terraces, and development of unpaired terraces but also due to development of a number of transverse faults, for example, Chaukhutiya and Raintoli $[10,23,26]$. Here, we investigate the NNW-SSE trending Raintoli Fault (RF), which shows the dextral or right lateral strike-slip movement along the Saryu valley from Seraghat to Seri. The quaternary reactivation of the RF may have been responsible for the landscape evolution of the area. In general, a series of cones and facets are developed within the trace of the fault. Generally, the triangular to polyhedral hill slopes are situated between two adjacent drainage structures within a given mountain front escarpment [56], which are generated by the recurrent faulting along the base of the escapements $[57,58]$ and mostly occur in the tectonically active areas [59]. 


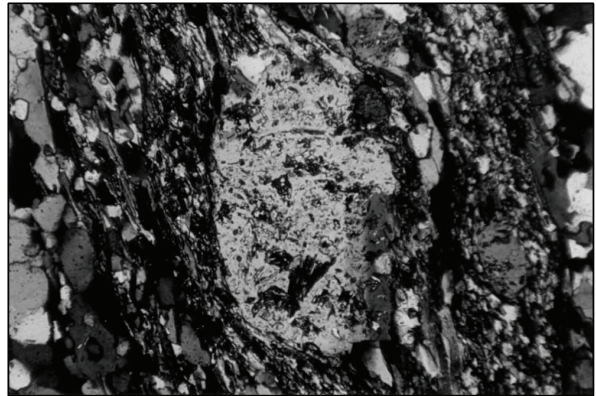

(a)

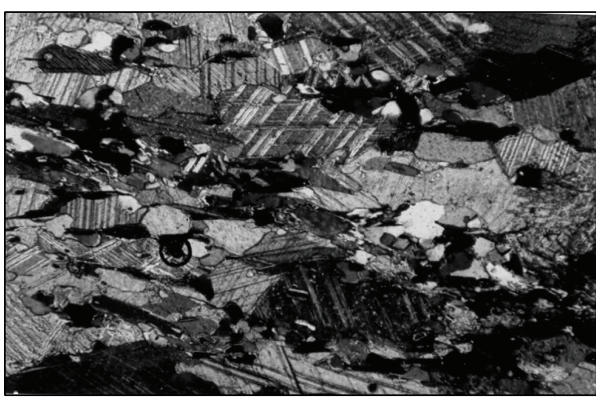

(c)

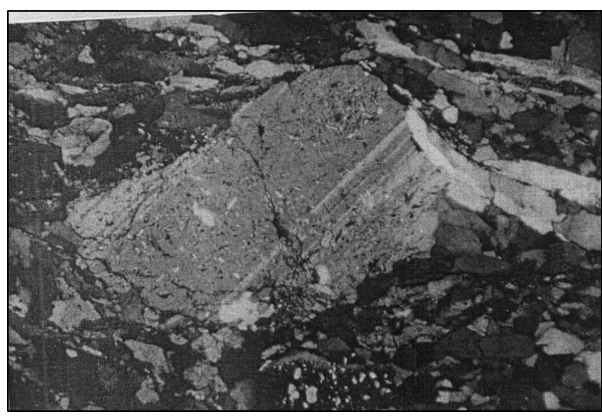

(e)

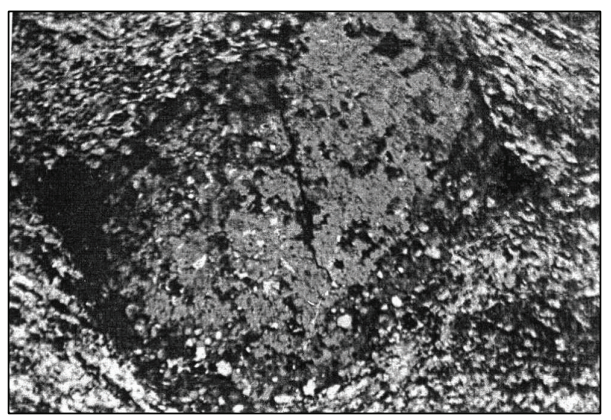

(g)

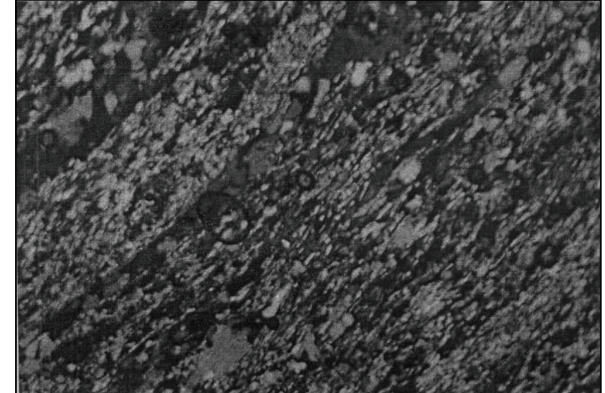

(b)

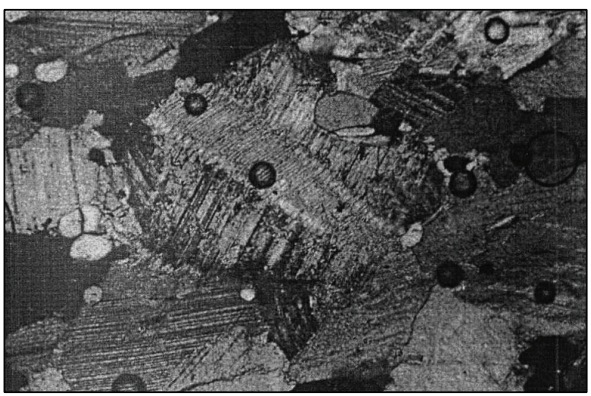

(d)

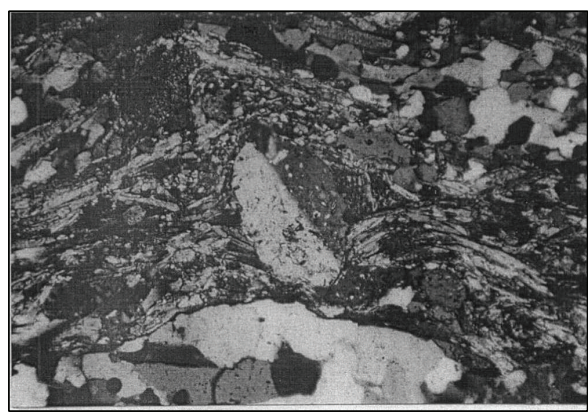

(f)

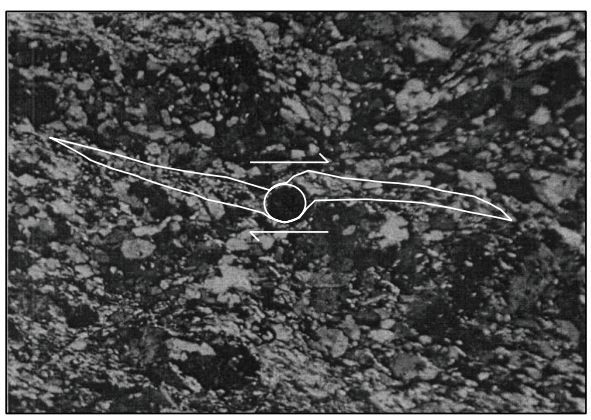

(h)

Figure 4: (a) Porphyroblasts of quartz and mica minerals in the Saryu Formation; (b) recrystallization in mylonitic rocks; (c) large calcite crystals in Deoban Formation showing deformation and a set of cleavage; (d) limestone with kink banded structures; (e) rotation of subgrain and grains boundary migration under recrystallization; (f) crystallized quartz crystals with sharp boundaries; (g) delta type structure; (h) sigma type structure.

The braiding of the river, series of triangular fault facets and cones, abandoned river channels (Figure 6(a)), entrenched meandering of river (Figure 6(b)), huge mass movement at right bank (see inset image of Figure 6(b)), old and stabilized landslide cones, and colluvial fans are prominent features in the studied area. Normal to incised meandering, river ponding, and three levels of river terraces at right bank near Nali-Naichun area with wide and V-shaped valleys point to 

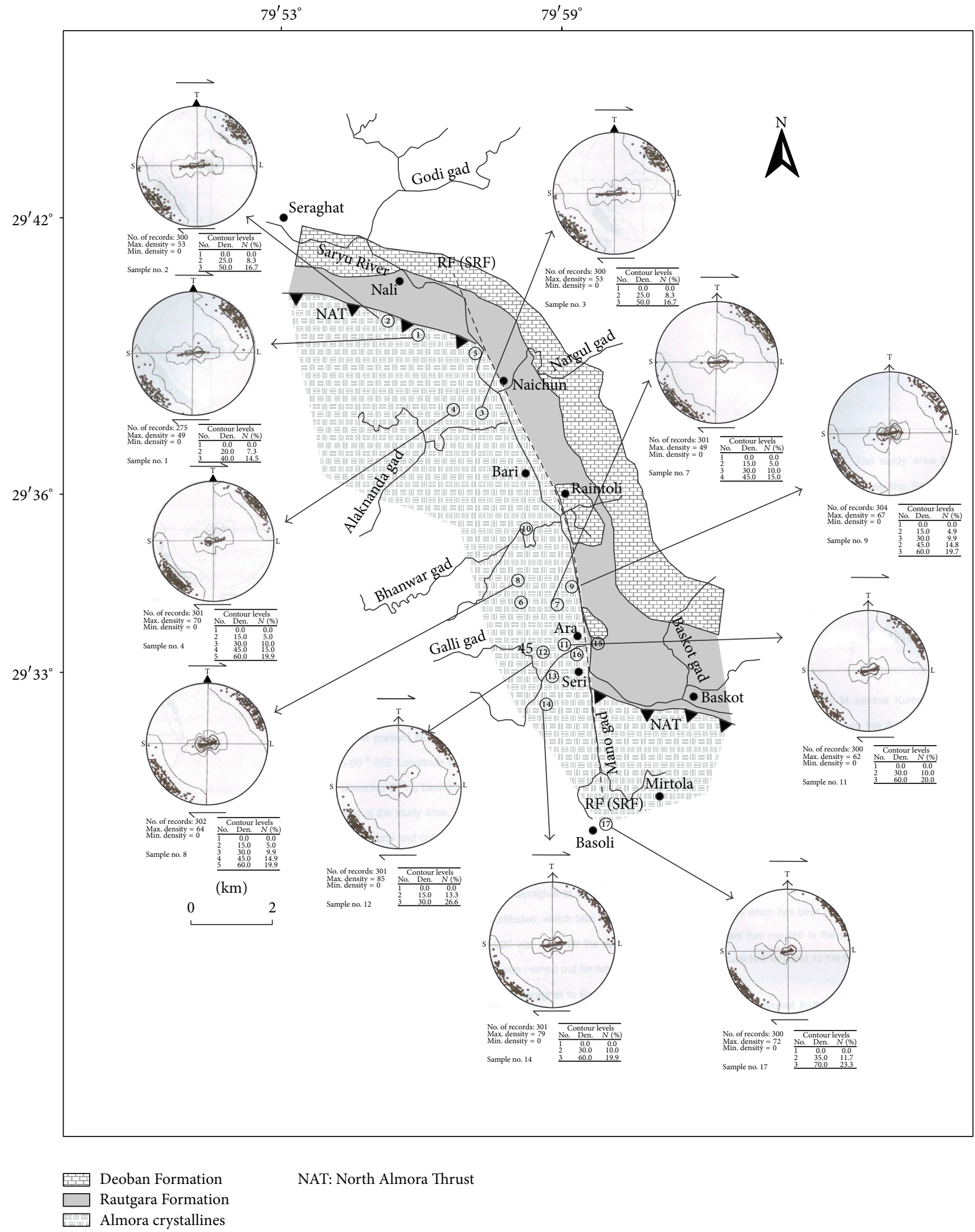

NAT: North Almora Thrust

FIGURE 5: Lower hemisphere stereo plot projection of quartz $c$-axis to record Lattice Preferred Orientation of grains in various samples (encircled numbers are samples for kinematic and quartz $c$-axis analysis) of the area. The preferred orientation shows down-dip (SW) movement. 


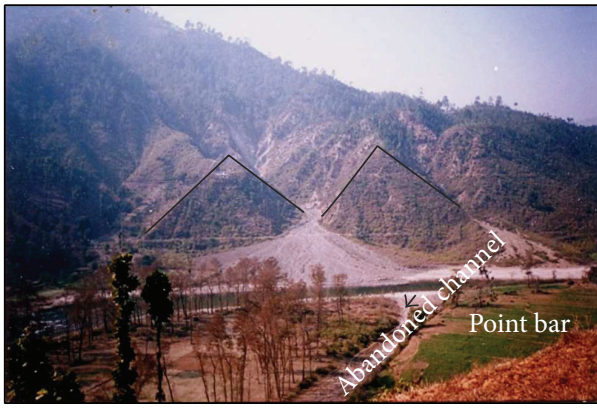

(a)

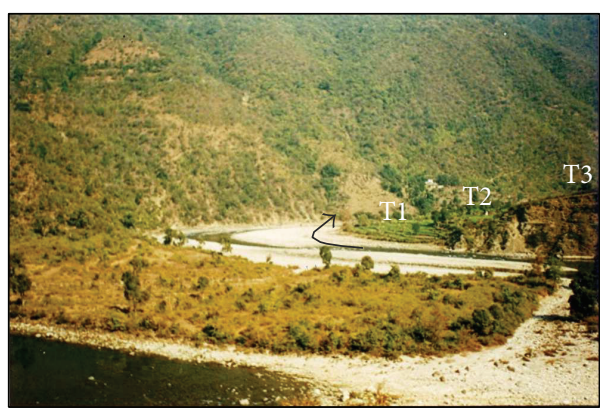

(c)

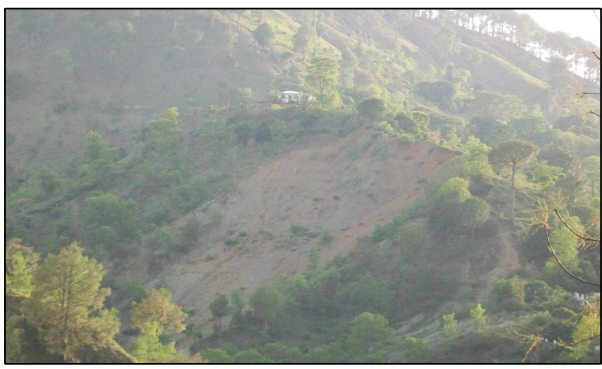

(e)

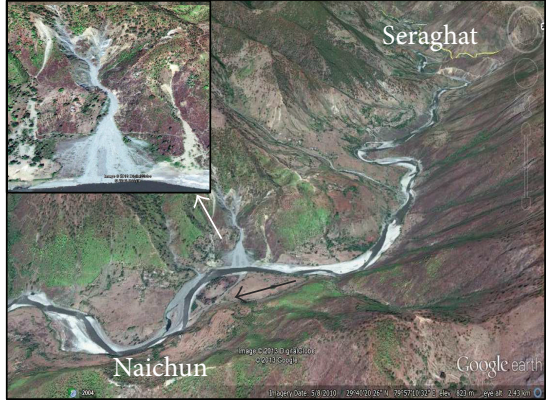

(b)

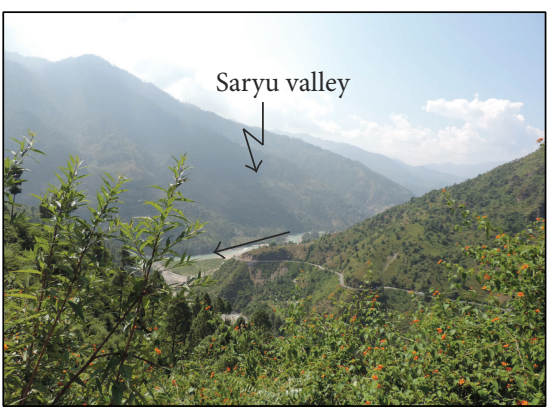

(d)

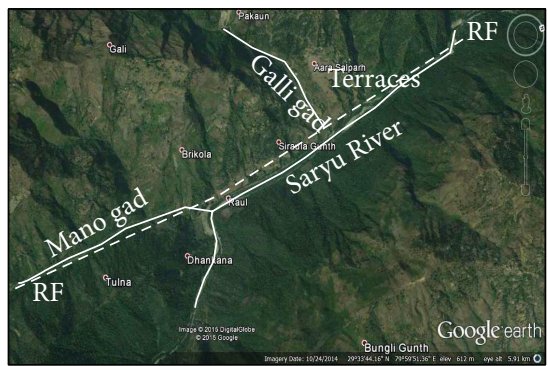

(f)

FIGURE 6: (a) Triangular fault facets, colluvial cones, point bar, and abandoned river channel near Naichun; (b) deflecting direction of river flow and meandering channel of Saryu River from Seraghat to Naichun and associated landslides, inset shows close view of huge mass movement activity at right bank of river; (c) meandering of Saryu River with three levels of terraces at Nali; (d) straight river channel with V-shaped valley; (e) landslide along the zone of NAT near Seraghat; (f) the straightening of the Mano gad, a tributary of Saryu River due to reactivation of RF with terrace at Ara.

the recent tectonic activity within the zone of NAT and RF (Figures 6(c) and 6(d)).

Generally, the Saryu River is very wide from Seraghat to Naichun along the zone of NAT (see Figure 6(a)). The movement along the NAT is suggested by the abandoned river channel with development of unpaired fluvial terraces with uplifting of a terrace about $44 \mathrm{~m}$ [22]. The continued compression along the NAT may also be suggested by the mass movement along the right bank of Saryu River (inset image in Figure 6(b)) and also along its tributary near Seraghat (Figure 6(e)). The sudden swing of Saryu River flow from NW-SE to almost N-S with the abrupt straightening and narrowing of the river valley, followed by the narrow gorge and slope break in river profile from Naichun to Seri, points to the quaternary reactivation of RF (Figures 7, 8(a), and 8(b)). The right lateral RF is also responsible for the straightening of the Mano gad, a tributary of Saryu River (see Figure 6(f)).
Pant et al. [22] mention the two phases of movements along the Saryu valley as result of not only reactivation $\mathrm{RF} / \mathrm{SRF}$, but also NAT. The tectonic rejuvenation of the RF/SRF not only has caused the tilting of terrace by $\sim 11^{\circ}$ towards north at Jateshwar temple near Raintoli, but also has been responsible for deposition of flood plain levee of Saryu River at Ara [22].

\subsection{Morphometric Analysis}

5.2.1. Sinuosity Indexes. The main contribution of drainage pattern within the basin is from right bank of the Saryu River along the RF (see Figure 1(c)). The 1st and 2nd orders of drainage systems are mostly oriented towards NNESSW with some towards NNW-SSE. However, the 3rd order pattern represents NNE-SSW and NNW-SSE dominated lineaments with the vector mean towards NNW-SSE. The NNW-SSE orientation of drainage pattern is influenced by 


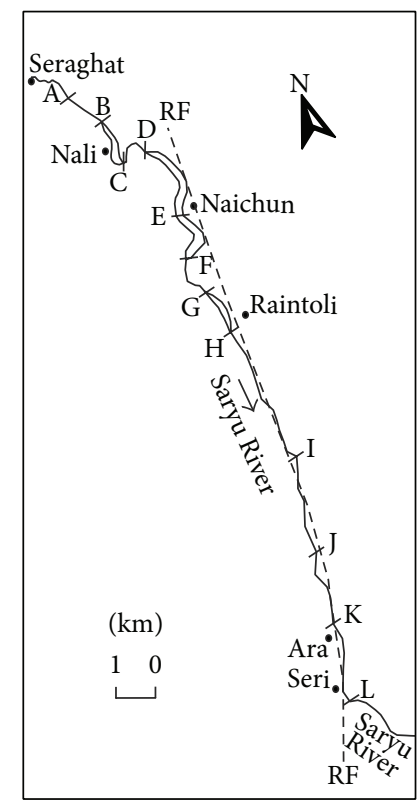

(a)

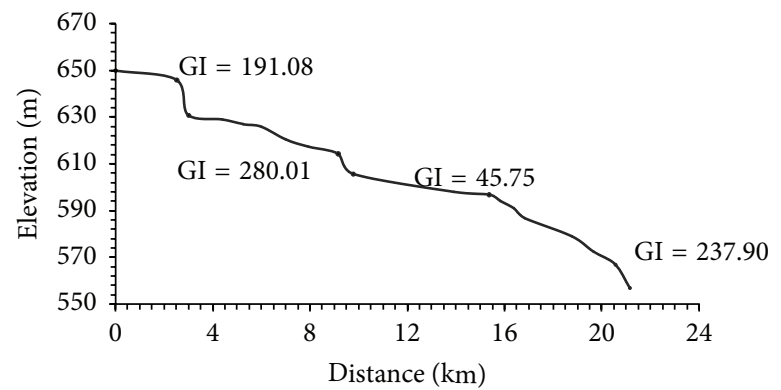

(c)

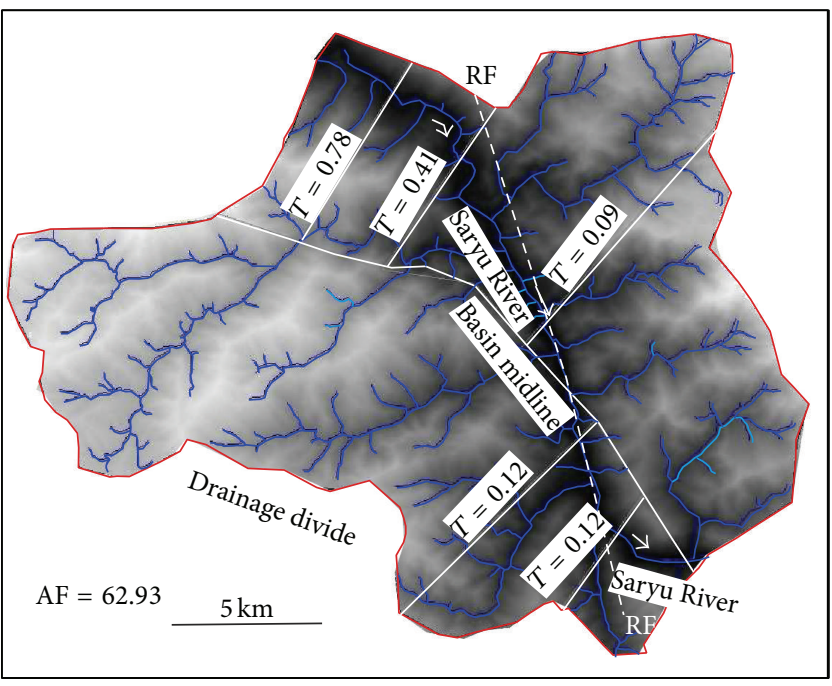

(b)

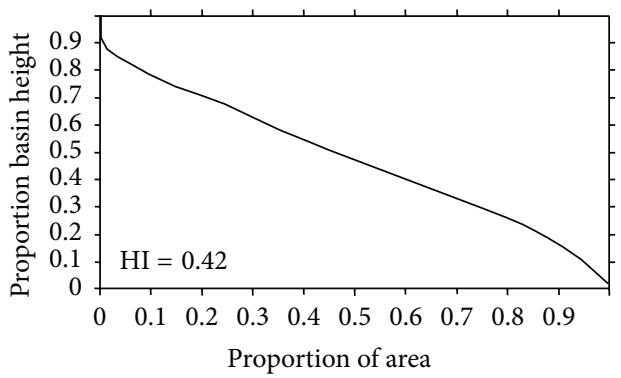

(d)

FIGURE 7: (a) Sinuosity segments along selected part of Saryu River for calculation of SSI, HSI, and TSI; (b) drainage basin along with asymmetry factor (AF) and transverse topographic symmetry factor $(T)$; (c) longitudinal profile of river with gradient index $(\mathrm{GI})$ values; (d) hypsometric curve and hypsometric integration (HI).

the NNW-SSE trending RF. The topographic features in the above sector also suggest that the drainage pattern is strongly controlled by multiple events of tectonic activity. During the first phase of tectonic activity, the NNW-SSE trending drainage was formed, whereas the latter phase may have created the NE-SW trending drainage. The drainage frequency and entrenchment are more prominent in the right bank compared to the left bank of the river. We assume that the entrenchment and high drainage frequency were due to the vertical upliftment in the Saryu River.

The Standard Sinuosity Index (SSI) values of 1.03-1.07 between $\mathrm{A}$ and $\mathrm{C}$ sections reveal straight to sinuous state of the river. The increased SSI $(\sim 1.60)$ in the bend C-D (see Figure 7 (a); Table 2) point to the meandering at locality Nali (see Figure 7(a)) as is also proved by the field investigations (see Figure 6(c)). The decreased SSI of 1.13 for bend D-E, 1.15 for bend E-F, and 1.19 for bend F-G indicate a nearly sinuous to braided river condition (Figure $7(\mathrm{a})$; Table 2 ). The river flows in nearly straight to sinuous state from points $\mathrm{G}$ to $\mathrm{K}$ and subsequently attains the braided state. The HSI seems more dominant than TSI from bend A to G and K to L, where the river becomes very wide and flows in braiding channels and forming terrace. In general, both HSI and SSI values from bend $\mathrm{H}$ to $\mathrm{K}$ ( $50 \%$ for both the parameters) signify narrow river course or a gorge (Table 2 ). The sinuosity parameters have earlier been used to understand the role of tectonism [60]. Muller [34] included the role of topographic factor while computing the sinuosity indices. The hydraulic sinuosity and topographic indices may be affected by climate but the latter also includes the component of tectonism, which can lead to the modification of slope and topography [61]. Our analysis suggests that the area is controlled not only by the topography but also by the hydraulic factor such as climate.

5.2.2. Drainage Basin Asymmetry. The asymmetry factor (AF) is measured to detect the tectonic tilting and degree of asymmetry in drainage basin $[35,62]$. The AF value above or below 50 may suggest tilting [35] and this can also be proved by the transverse topographic symmetry factor $(T)$. When the $T$ increases, asymmetry is increased and thus $T=0$ means 
TABLE 2: Sinuosity parameters calculated for various segments from Seraghat to Seri (see Figure 7(a)).

\begin{tabular}{lcccccccc}
\hline Sector/bend & CL & VL & AL & CI & VI & SSI & HSI (\%) \\
\hline A-B & 1033.33 & 1000 & 966.67 & 1.07 & 1.03 & 1.03 & 50 \\
B-C & 1200 & 1116.67 & 1066.67 & 1.12 & 1.05 & 1.07 & 62 & TSI (\%) \\
C-D & 1066.67 & 666.67 & 600 & 1.78 & 1.11 & 1.60 & 86 \\
D-E & 2000 & 1766.67 & 1666.67 & 1.20 & 1.06 & 1.13 & 70 & 14 \\
E-F & 1266.67 & 1100 & 1000 & 1.27 & 1.10 & 1.15 & 63 & 38 \\
F-G & 1266.67 & 1066.67 & 933.33 & 1.36 & 1.14 & 1.19 & 60 & 57 \\
G-H & 1266.67 & 1166.67 & 1066.67 & 1.19 & 1.09 & 1.09 & 50 \\
H-I & 1866.67 & 1800 & 1733.33 & 1.08 & 1.04 & 1.04 & 50 \\
I-J & 1800 & 1733.33 & 1666.67 & 1.08 & 1.04 & 1.04 & 50 \\
J-K & 2533.33 & 2466.67 & 2400 & 1.06 & 1.03 & 1.03 & 50 \\
K-L & 2133 & 1800 & 1733.33 & 1.23 & 1.04 & 1.19 & 50 & 53 \\
\hline
\end{tabular}

a perfect symmetric basin $[19,35,63]$. In our study, the $\mathrm{AF}$ was measured as 62.93 for selected parts of the Saryu River (see Figure 7(b)) in which the AF > 50 may point to the tectonic tilt to the left (looking downstream), reflecting the uplift in opposite direction. We observed that most of the terraces on the right bank are elevated compared to the left bank. Similarly, the $T$ values from 0.09 to 0.78 (Figure 7(b)) imply the ground tilting of the Saryu River basin.

5.2.3. Longitudinal Profiles and Stream Gradient Index. The longitudinal profile is used to identify the tectonic and river response as it is a graph of the relationship between river elevation and river length [37]. The longitudinal profiles of the river show irregular pattern which might reflect disequilibrium conditions, suggesting uplift along active faults [56]. The sudden break in the river profile suggests the presence of knick points along the slope (Figure $7(\mathrm{c})$ ). The river gradient is nearly $100 \mathrm{~m}$ from Seraghat to Seri where the NAT and RF follow the river (see Figure 7(c)). Thus, the increase in gradient even to the order of only $1^{\circ}$ can promote incision and the head ward erosion of streams [64] and can also enhance the development of uptilted tributaries $[65,66]$. The steep slopes along the knick points indicate differential uplift along channel or a disequilibrium state of channels due to tectonic and climatic perturbations (Figure 7(c)). Further, the gradient index (GI) is used to understand the uplift along the knick points as it is a measure of perturbation along longitudinal profile and detects the recent tectonic activity by anomalously high index value [37]. The GI value oscillates from Seraghat to Seri between 34.98 and 280.01 (Figure 7(c)). Thus, the higher GI values suggest the relatively higher tectonic upliftment. It is also suggested by the various geomorphic features along the Seraghat to Naichun, for example, river terraces, meandering path, and mass movement. In middle part the lower GI values are also supported by the deployment of river terraces and straightening of river valley between Raintoli and Ara. Further, the GI values (237) which are high at lower catchment show the higher tectonic activity as also suggested by the three levels of river terrace with natural levee deposits at Ara [22]. Thus, the almost higher values of GI also reflect the higher tectonic activity within the zone of NAT and RF.
5.2.4. Hypsometric Curve and Hypsometric Integration (HI). Hypsometric curve is essentially a normalized cumulative frequency distribution of elevation [67], whereas the hypsometric integral (HI) is the area beneath the curve which is related to the percentage of total relief to cumulative percent of area. The HI represents the relative distribution of elevation in a given area of a landscape particularly a drainage basin [67]. Thus, the hypsometric curves and integrals can be interpreted in terms of degree of basin dissection and relative landform age; convex-up curves with high integrals are typical for youth, undissected (disequilibrium stage) landscapes; smooth, S-shaped curves crossing the center of the diagram characterize mature (equilibrium stage) landscapes; and concave-up with low integrals characterized old and deeply dissected landscapes [67]. Dehbozorgi et al. [68] also classified the hypsometric curves according to the convexity or concavity: class 1 with convex curves $(\mathrm{HI} \geq$ $0.5)$; class 2 with concave-convex $(0.4 \leq \mathrm{HI}<0.5)$; and class 3 with concave curves $(\mathrm{HI}<0.4)$. Here, the HI values of selected drainage basins of the Saryu River are about 0.42, representing concave-convex hypsometric curves and thus mature stage of the river (see Figure $7(\mathrm{~d})$ ). The hypsometric curves of the studied basin are concave at upper part and convex in the lower portion (Figure $7(\mathrm{~d})$ ). The convexity in the lower portion of the hypsometric curve in the Saryu basin may be due to uplift along the zone NAT and RF [69].

5.2.5. Ratio of Valley Floor Width to Valley Height $\left(V_{f}\right)$. The $V_{f}$ was calculated with the help of GIS software at different locations of the Saryu River (Figure 8(a)). The higher $V_{f}$ values along A-B and C-D sections (see Figure 8(b)) point to the wide and flat valley floors. The reduced $V_{f}$ values along the sectors E-F (0.43), G-H (0.35), and I-G (0.6) suggest that the river actively incises its bed and flows along a relatively active mountain front and is subjected to pronounced upliftment and accelerated erosion [35, 69]. Generally, the $V_{f}$ values along the studied river are relatively low, thus indicating deep and narrow "V-" shaped valleys, and can be assigned to have undergone rapid upliftment [70]. Our field observations also show that the RF follows the path of the river at such points. The river attains a straight path along the $\mathrm{V}$-shaped valley with increased erosional activity (see Figures 6(b) and 6(f)). 


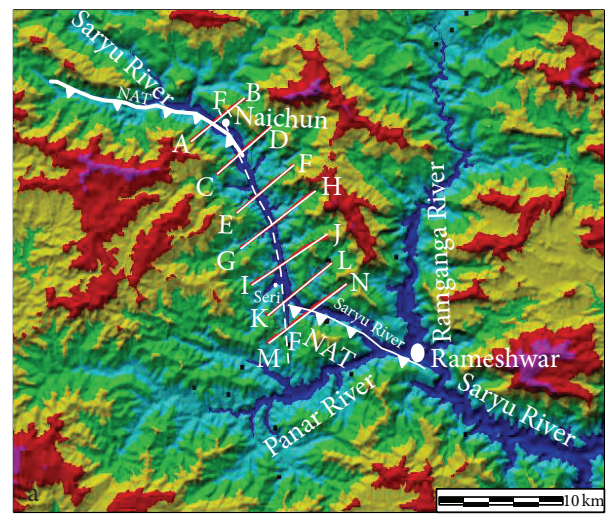

(a)
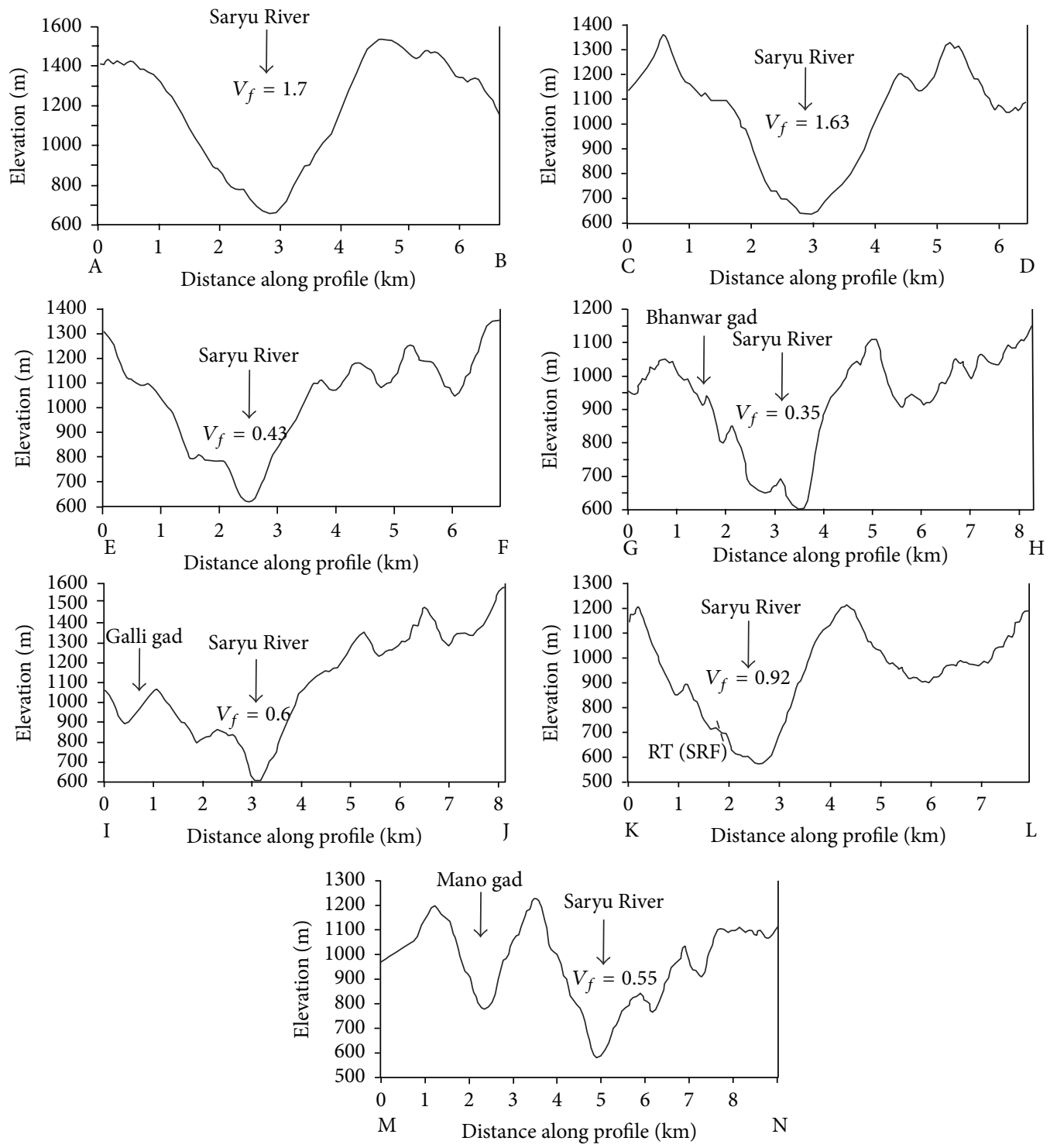

(b)

FIGURE 8: (a) SRTM based DEM of Saryu River valley reflecting the tectonically controlled dendritic drainage pattern. The A-B, C-D, E-F, G-H, I-J, K-L, and M-N are cross sections along the RF to calculate the Valley Floor Width to Valley Height; (b) river profiles with V-shaped valley along the RF. Slightly wider valley profiles along A-B and C-D suggest that the area may have been controlled by both climate and tectonics. $V_{f}$ values are mentioned in each profile. 


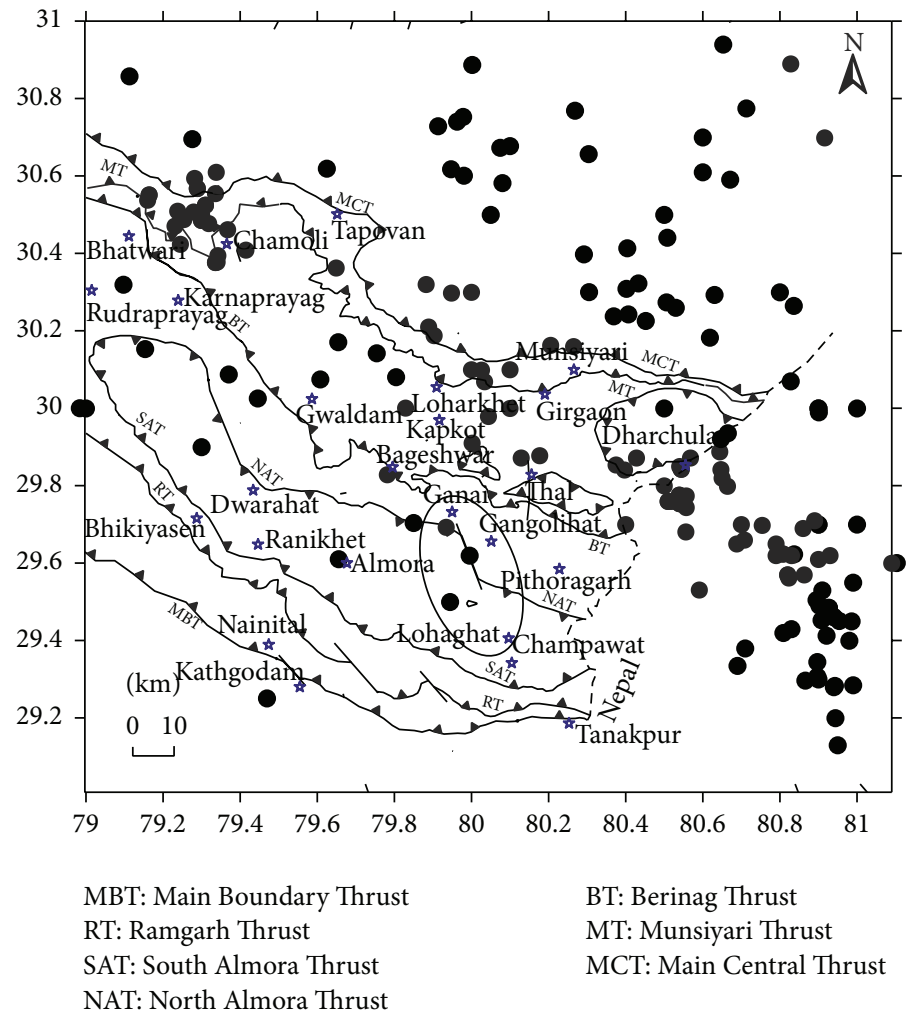

FIGURE 9: Epicentral distribution of earthquake events using USGS and EHB events. The oblate circle showing the studied sector with microseismicity [72].

The $V_{f}$ values indicate that the river is deeply incised into the ground when it flows over an active fold or fault as has also been suggested by Dehbozorgi et al. [68] and Bull and McFadden [71]. The high values of $V_{f}$ in the study area are encountered at places where the RF comes in contact with the NAT.

\section{Seismicity around the Area}

The Himalayan region has experienced a number of M8 and M5-M7.8 magnitude earthquakes in the present century [73]. Pathak et al. [72] suggested that the entire Kumaun Himalaya is seismically active especially the northern part of the Lesser Himalaya and also pointed out that the SAT and NAT are relatively active. A GPS based research by Ponraj et al. [74] and Dumka et al. [75, 76] revealed that a maximum strain was accumulated in the northern part. Philip et al. [73] also argued that the tectonic activity along the active faults may also be responsible for ongoing seismicity within the region. Thus, the neotectonic activity as documented by the various geomorphic indicators and recurring movements along the faults within the region are in coherence with the epicentral distributions of small to moderate earthquakes around the study region (Figure 9).

\section{Discussion and Conclusion}

The RF is characterized by the right lateral strike-slip fault which runs parallel to the NAT for about $20 \mathrm{~km}$ along the Saryu valley from Seraght-Naichun-Raintoli to Seri section in the Central Kumaun Himalaya. The structural data suggest two phases of deformation, for example, $D_{1}$ and $D_{2}$, the former is related to the development of schistosity and affected by tight to isoclinal folds and the latter may have resulted due to the development of crenulation cleavage. Similar conclusion has also been drawn by Joshi and Tiwari [9] in the rocks of the Saryu Formation of Almora nappe. The C-S structures in mylonites indicate SW to $\mathrm{S}$ movement as a consequence of continued compression of the Lesser Himalayan rocks. The macro- and microscopic features in the zone of RF are characterized by the mylonite belts and reduction of grain size with ribbonlike structure of mica grains and also a strong schistosity, pointing to the ductile deformation. Pant et al. [26] also suggested that the zone of mylonitic rocks has developed due to strain localization along the NAT. The fault kinematics also reveals the dextral shear for the RF by development of delta and sigma type of porphyroblast. The shear sense indicators such as asymmetric porphyroclasts, mica fish, and microfaulting indicate syn-deformation pattern. The Lattice Preferred Orientation (LPO) of quartz $c$-axis fabric shows an asymmetrical or monoclinic fabric and asymmetry of girdles pointing to dextral shear, indicating a top to S/SW movement.

The ductile shear zones are generally reactivated as strikeslip, normal, and oblique-slip faults [77]. In our area, fine grained mylonites may have continued shearing along the 
zone of the NAT and perhaps were responsible to make the region prone to brittle reactivation due to intensified tectonic activity in the Himalaya. Although the mylonite zones exposed in old rocks at the Earth's surface by uplift and erosion are generally considered to represent the deep portions of once active faults [78, 79], the ancient exposed mylonite zones, on the other hand, have usually lost the corresponding upper brittle portion [80]. Thus, the ductile shearing of the area related to the continued compression along the NAT and the geomorphic activity could correspond to the reactivation of NAT as well as laterally formed fault, for example, RF.

The recrystallization of the rocks since the orogenic phase together with the quaternary geomorphic activity may have been related to increased seismic activity and consequent natural hazards in the vicinity of NAT and RF. However, no large instrumentally recorded earthquakes have been attributed to the NAT and RF and only a few small and moderate events are recorded. Since these data correspond to the youngest activity, they are in agreement with the geomorphic observations of a kinematic changeover from ductile to brittle-ductile deformation of recent right lateral strike-slip faulting within the zone of NAT. It also suggested that the brittle faults affected the basal shear zone of Almora nappe and represent the postshear zone structures formed as a consequence of neotectonic movements in response to still continuing compression due to northward movement of the Indian Plate [9]. The geomorphic and structural feature along the NAT may suggest the transpressional tectonic as recognized by the meandering and aggradation of sediment in form of river terraces at Nali and Naichun and natural levee flood plain deposit at the Ara and tilting of terrace. Further, the triangular cones and facets, huge landslide fans, and wide valley perhaps indicate the initiation of dip-slip component over the strike-slip Raintoli Fault and perhaps suggest the transtensional tectonic along the part of Saryu valley.

The neotectonic reactivation of the fault is further evident by wide and straight course of river, triangular fault facets, abandoned river channels, unpaired fluvial terraces, braiding nature of the river, and microseismic activity within the region. The recent tectonic activity is also manifested by morphometric parameters, which indicate that the area is strongly controlled by bedrock, hill slope, and stream processes under the influence of climate and tectonics. The titling of drainage basin, sinuosity pattern of river, $\mathrm{V}$-shaped valley, and disequilibrium state of the river as well as upliftment of valley wall also point to the prominent evidences of tectonic activity along the RF in the zone of NAT. The reactivation of the RF is also documented using ongoing landscape evolution in form of the geomorphic features and recurring seismicity within the region.

\section{Conflict of Interests}

The authors declare that there is no conflict of interests regarding the publication of this paper.

\section{Acknowledgments}

The Lalit M. Joshi is thankful to SERB (DST), New Delhi for Fast Track project (no. SR/FTP/ES-91/2012). Further financial assistance was provided to Bahadur S. Kotlia by the UGC and CSIR, New Delhi. The authors are grateful to R. C. Upadhayay for his untiring help during laboratory work. Centre of Advanced Study in Geology, Kumaun University, Nainital, is highly acknowledged for providing working facilities. Dr. R. Carosi is thankfully acknowledged for reviewing the paper.

\section{References}

[1] A. Gansser, Geology of the Himalayas, Interscience, John Wiley \& Sons, London, UK, 1964.

[2] A. Heim and A. Gansser, "Central Himalaya: geological observations of the Swiss Expedition of 1936," in Memoires de la Societe Helvetique Sciences Naturelles, vol. 73, pp. 1-245, 1939.

[3] T. Ahmad, N. Harris, M. Bickle, H. Chapman, J. Bunbury, and C. Prince, "Isotopic constraints on the structural relationships between the Lesser Himalayan Series and the High Himalayan Crystalline Series, Garhwal Himalaya," Bulletin of the Geological Society of America, vol. 112, no. 3, pp. 467-477, 2000.

[4] P. G. DeCelles, D. M. Robinson, J. Quade et al., "Stratigraphy, structure, and tectonic evolution of the Himalayan fold-thrust belt in Western Nepal," Tectonics, vol. 20, no. 4, pp. 487-509, 2001.

[5] S. Mandal, D. M. Robinson, S. Khanal, and O. Das, "Redefining the tectonostratigraphic and structural architecture of the Almora klippe and the Ramgarh-Munsiari thrust sheet in NW India," Geological Society, London, Special Publications, vol. 412, no. 1, pp. 247-269, 2015.

[6] K. S. Valdiya and B. S. Kotlia, "Fluvial geomorphic evidence for Late Quaternary reactivation of a synclinally folded nappe in Kumaun Lesser Himalaya," Journal of the Geological Society of India, vol. 58, no. 4, pp. 303-317, 2001.

[7] M. Joshi, "Evolution of the basal shear zone of the Almora Nappe, Kumaun Himalaya," Memories Gondwana Research, vol. 6, pp. 69-80, 1999.

[8] M. Joshi and A. N. Tiwari, "Quartz C-axes and metastable phases in the metamorphic rocks of Almora Nappe: evidence of Pre-Himalayan signatures," Current Science, vol. 87, no. 7, pp. 995-999, 2004.

[9] M. Joshi and A. N. Tiwari, "Structural events and metamorphic consequences in Almora Nappe, during Himalayan collision tectonics," Journal of Asian Earth Sciences, vol. 34, no. 3, pp. 326335, 2009.

[10] K. S. Valdiya, "Himalayan transverse faults and folds and their parallelism with subsurface structures of North Indian plains," Tectonophysics, vol. 32, no. 3-4, pp. 353-386, 1976.

[11] K. S. Valdiya, "Neotectonic activity in the himalayan belt," in Proceedings of the International Symposium on Neotectonics in South Asia, Survey of India, pp. 241-267, Dehra Dun, India, February 1986.

[12] K. S. Valdiya, "Uplift and geomorphic rejuvenation of the Himalaya in the Quaternary period in the Quaternary history of India," Current Science, vol. 64, pp. 873-885, 1993.

[13] K. S. Valdiya, B. S. Kotlia, P. D. Pant et al., "Quaternary palaeolakes in Kumaun Lesser Himalaya: finds of neotectonic and palaeoclimatic significance," Current Science, vol. 70, no. 2, pp. 157-161, 1996. 
[14] P. D. Pant, O. P. Goel, and M. Joshi, "Neotectonic movements in the Loharkhet area, District Almora, Kumaun Himalaya," Journal of Geological Society of India, vol. 39, no. 3, pp. 245-253, 1992.

[15] B. S. Kotlia, M. S. Bhalla, C. Sharma et al., "Palaeoclimatic conditions in the upper Pleistocene and Holocene BhimtalNaukuchiatal lake basin in south-central Kumaun, North India," Palaeogeography, Palaeoclimatology, Palaeoecology, vol. 130, no. 1-4, pp. 307-322, 1997.

[16] B. S. Kotlia, J. Sanwal, B. Phartiyal, L. M. Joshi, A. Trivedi, and C. Sharma, "Late Quaternary climatic changes in the eastern Kumaun Himalaya, India, as deduced from multi-proxy studies," Quaternary International, vol. 213, no. 1-2, pp. 44-55, 2010.

[17] B. S. Kotlia and L. M. Joshi, "Neotectonic and climatic impressions in the zone of Trans Himadri Fault (THF), Kumaun Tethys Himalaya, India: a case study from palaeolake deposits," Zeitschrift für Geomorphologie, vol. 57, no. 3, pp. 289-303, 2013.

[18] P. K. Goswami and C. C. Pant, "Morphotectonic evolution of the Binau-Ramganga-Naurar transverse valley, southern Kumaun Lesser Himalaya," Current Science, vol. 94, no. 12, pp. 1640-1645, 2008.

[19] L. M. Joshi and B. S. Kotlia, "Neotectonically triggered instability around the palaeolake regime in Central Kumaun Himalaya, India," Quaternary International, vol. 371, pp. 219-231, 2014.

[20] L. Godin, "Structural evolution of the Tethyan sedimentary sequence in the Annapurna area, central Nepal Himalaya," Journal of Asian Earth Sciences, vol. 22, no. 4, pp. 307-328, 2003.

[21] K. S. Valdiya, Geology of Kumaun Lesser Himalaya, Wadia Institute of Himalayan Geology, Himachal Times Press, Dehradun, India, 1980.

[22] P. D. Pant, G. C. Kothyari, and K. Luirei, "Geomorphological and geological investigations of neotectonic activity of Saryu River Faults (SRF), a part of North Almora Thrust (NAT) in Seraghat-Basoli area in Central Kumaun, Uttaranchal," Journal of Geological Society of India, vol. 70, pp. 815-823, 2007.

[23] G. C. Kothyari, Quaternary reactivation of North Almora Thrust (NAT) in central Kumaun implication to neotectonic rejuvenation lesser Himalaya uttaranchal [Ph.D. thesis], Lambert Publication House, Saarbrücken, Germany, 2010.

[24] A. Richards, T. Argles, N. Harris et al., "Himalayan architecture constrained by isotopic tracers from clastic sediments," Earth and Planetary Science Letters, vol. 236, no. 3-4, pp. 773-796, 2005.

[25] J. Célérier, T. M. Harrison, A. Yin, and A. A. G. Webb, "The Kumaun and Garwhal Lesser Himalaya, India: part 1. Structure and stratigraphy," Bulletin of the Geological Society of America, vol. 121, no. 9-10, pp. 1262-1280, 2009.

[26] P. D. Pant, R. Chauhan, and S. S. Bhakuni, "Development of transverse fault along North Almora Thrust, Kumaun Lesser Himalaya, India: a study based on field and magnetic fabrics," Journal of the Geological Society of India, vol. 79, no. 5, pp. 429448, 2012.

[27] G. S. Lister and G. P. Price, "Fabric development in a quartzfeldspar mylonite," Tectonophysics, vol. 49, no. 1-2, pp. 37-78, 1978.

[28] C. Simpson and S. M. Schmid, "An evaluation of criteria to deduce the sense of movement in sheared rocks," Geological Society of America Bulletin, vol. 94, no. 11, pp. 1281-1288, 1983.

[29] G. S. Lister and A. W. Snoke, "S-C mylonites," Journal of Structural Geology, vol. 6, no. 6, pp. 617-638, 1984.
[30] R. D. Law, "Heterogeneous deformation and quartz crystallographic fabric transitions: natural examples from the Moine thrust zone at the Stack of Glencoul, northern Assynt," Journal of Structural Geology, vol. 9, no. 7, pp. 819-833, 1987.

[31] C. W. Passchier and R. A. J. Trouw, Microtectonics, Springer, Berlin, Germany, 1996.

[32] F. J. Turner and L. E. Weiss, Structural Analysis of Metamorphic Tectonites, McGraw-Hill, New York, NY, USA, 1963.

[33] T. S. Kutty and S. Joy, "Sternet-a computer program for stereographic projection: with a new algorithm for contouring," Journal of the Geological Society of India, vol. 50, no. 5, pp. 649$653,1997$.

[34] J. E. Muller, "An introduction to the hydraulic and topographic sinuosity indexes," Annals of the Association of American Geographers, vol. 58, no. 2, pp. 371-385, 1968.

[35] E. A. Keller and N. Pinter, Active Tectonics: Earthquakes, Uplift, and Landscape, Prentice-Hall, Upper Saddle River, NJ, USA, 1996.

[36] R. T. Cox, "Analysis of drainage-basin symmetry as a rapid technique to identify areas of possible Quaternary tilt-block tectonics: an example from the Mississippi Embayment," Geological Society of America Bulletin, vol. 106, no. 5, pp. 571-581, 1994.

[37] S. Rhea, "Geomorphic observations of rivers in the Oregon Coast Range from a regional reconnaissance perspective," Geomorphology, vol. 6, no. 2, pp. 135-150, 1993.

[38] R. W. Schlische, "Geometry and origin of fault-related folds in extensional settings," AAPG Bulletin, vol. 79, no. 11, pp. 1661$1678,1995$.

[39] S. K. Ghosh, Structural Geology: Fundamentals and Modern Developments, Pergamon Press, New York, NY, USA, 1993.

[40] R. D. Law, R. J. Knipe, and H. Dayan, "Strain path partitioning within thrust sheets: microstructural and petrofabric evidence from the Moine Thrust zone at Loch Eriboll, northwest Scotland," Journal of Structural Geology, vol. 6, no. 5, pp. 477-497, 1984.

[41] R. D. Law, "Crystallographic fabrics: a selective review of their applications to research in structural geology," in Deformation Mechanisms, Rheology and Tectonics, R. J. Knipe and E. H. Rutter, Eds., vol. 54, pp. 335-352, Geological Society of London, 1990.

[42] J. P. Platt and J. H. Behrmann, "Structures and fabrics in a crustal scale shear zone, Betic Cordillera, SE Spain," Journal of Structural Geology, vol. 8, no. 1, pp. 15-35, 1986.

[43] E. Fazio, R. Punturo, and R. Cirrincione, "Quartz C-axis texture mapping of mylonitic metapelite with rod structures (Calabria, southern Italy): clues for hidden shear flow direction," Journal of the Geological Society of India, vol. 75, no. 1, pp. 171-182, 2010.

[44] R. Carosi, C. Montomoli, D. Rubatto, and D. Visonà, "Late Oligocene high-temperature shear zones in the core of the Higher Himalayan Crystallines (Lower Dolpo, Western Nepal)," Tectonics, vol. 29, no. 4, Article ID TC4029, 2010.

[45] C. Montomoli, S. Iaccarino, R. Carosi, A. Langone, and D. Visonà, "Tectonometamorphic discontinuities within the Greater Himalayan Sequence in Western Nepal (Central Himalaya): insights on the exhumation of crystalline rocks," Tectonophysics, vol. 608, pp. 1349-1370, 2013.

[46] C. Simpson, "Deformation of granitic rocks across the brittleductile transition," Journal of Structural Geology, vol. 7, no. 5, pp. 503-511, 1985. 
[47] L. M. Joshi, Tertiary fault kinematics of the Saryu River Fault (SRF) in central Kumaun, district Almora, Uttaranchal [M.S. thesis], Kumaun University Nainital, In press.

[48] I. Hara, K. Takeda, and T. Kimura, "Preferred lattice orientation of Quartz in shear deformation," Journal of Science of the Hiroshima University Series C, vol. 7, pp. 1-11, 1973.

[49] C. J. L. Wilson, "Preferred orientation in quartz ribbon mylonites," Geological Society of America Bulletin, vol. 86, pp. 968-974, 1975.

[50] J.-L. Bouchez, "Plastic deformation of quartzites at low temperature in an area of natural strain gradient," Tectonophysics, vol. 39, no. 1-3, pp. 25-50, 1977.

[51] G. S. Lister and P. F. Williams, "Fabric development in shear zones: theoretical controls and observed phenomena," Journal of Structural Geology, vol. 1, no. 4, pp. 283-297, 1979.

[52] G. F. Becker, "Schistosity and slaty cleavage," The Journal of Geology, vol. 4, no. 4, pp. 429-448, 1896.

[53] G. H. Eisbacher, "Deformation mechanics of mylonitic rocks and fractured granites in Cobequid Mountains, Nova Scotia, Canada," The Geological Society of America Bulletin, vol. 81, no. 7, pp. 2009-2020, 1970.

[54] J. L. Bouchez and A. Pecher, Plasticité du Quartz et Sens de Cisaillerilent Dans les Quartzites du Graiid Chevauchement Central Himalayen, vol. 18 of Bulletin de la Societe Geologique de France, 1976.

[55] J. P. Burg and P. H. Laurent, "Strain analysis of a shear zone in a granodiorite," Tectonophysics, vol. 47, no. 1-2, pp. 15-42, 1978.

[56] M. T. Ramírez-Herrera, "Geomorphic assessment of active tectonics in the Acambay Graben, Mexican volcanic belt," Earth Surface Processes and Landforms, vol. 23, no. 4, pp. 317-332, 1998.

[57] W. B. Bull, "Geomorphic tectonic classes of the south front of the San Gabriel Mountains, California," US Geological Survey Contact Report 14-08-001-G-394, 1978.

[58] W. B. Bull, “Tectonic geomorphology," Journal of Geological Education, vol. 32, no. 5, pp. 310-324, 1984.

[59] S. G. Wells, T. F. Bullard, C. M. Menges et al., "Regional variations in tectonic geomorphology along a segmented convergent plate boundary pacific coast of Costa Rica," Geomorphology, vol. 1, no. 3, pp. 239-265, 1988.

[60] R. Raj, N. Mulchandani, S. Bhandari, D. M. Maurya, and L. S. Chamyal, "Channel shifting of a highly sinuous meandering river in alluvial plain, Vishwamitri River, Mainland Gujarat," Current Science, vol. 86, no. 12, pp. 1647-1653, 2004.

[61] S. Jain and P. K. Verma, "Drainage characteristics of tectonically active areas: an example from Rajasthan, India," International Journal of Economic and Environment Geology, vol. 1, pp. 11-16, 2011.

[62] N. Pinter, Exercises in Active Tectonics-An Introduction to Earthquakes and Tectonic Geomorphology, Prentice-Hall, Upper Saddle River, NJ, USA, 1996.

[63] B. Phartiyal and G. C. Kothyari, "Impact of neotectonics on drainage network evolution reconstructed from morphometric indices: case study from NW Indian Himalaya," Zeitschrift für Geomorphologie, vol. 56, no. 1, pp. 121-140, 2012.

[64] R. E. Horton, "Erosional development of streams and their drainage basins; hydrophysical approach to quantitative morphology," Bulletin of the Geological Society of America, vol. 56, no. 3, pp. 275-370, 1945.

[65] R. T. Cox, R. B. Van Arsdale, and J. B. Harris, "Identification of possible Quaternary deformation in the Northeastern Mississippi embayment using quantitative geomorphic analysis of drainage-basin asymmetry," Bulletin of the Geological Society of America, vol. 113, no. 5, pp. 615-624, 2001.

[66] P. K. Goswami and T. Deopa, "Quaternary block-tilting in southern Himalayan ranges of eastern Uttarakhand, India," Zeitschrift für Geomorphologie, vol. 57, no. 1, pp. 45-60, 2013.

[67] A. N. Strahler, "Hypsometric (area-altitude) analysis of erosional topography," Bulletin of the Geological Society of America, vol. 63, no. 11, pp. 1117-1142, 1952.

[68] M. Dehbozorgi, M. Pourkermani, M. Arian, A. A. Matkan, H. Motamedi, and A. Hosseiniasl, "Quantitative analysis of relative tectonic activity in the Sarvestan area, central Zagros, Iran," Geomorphology, vol. 121, no. 3-4, pp. 329-341, 2010.

[69] R. El-Hamdouni, C. Irigaray, T. Fernández, J. Chacón, and E. A. Keller, "Assessment of relative active tectonics, southwest border of the Sierra Nevada (southern Spain)," Geomorphology, vol. 96, no. 1-2, pp. 150-173, 2008.

[70] V. S. Kale and N. Shejwalkar, "Uplift along the western margin of the Deccan Basalt Province: is there any geomorphometric evidence?" Journal of Earth System Science, vol. 117, no. 6, pp. 959-971, 2008.

[71] W. B. Bull and L. D. McFadden, "Tectonic geomorphology north and south of the Garlock fault, California," in Geomorphology in Arid Regions: Proceedings of the Eighth Annual Geomorphology Symposium, State University of New York at Binghamton, Binghamton, September 23-24, D. O. Doehring, Ed., pp. 115-138, 1977.

[72] V. Pathak, C. C. Pant, and G. S. Darmwal, "Geomorphological and seismological investigations in a part of western Kumaun Himalaya, Uttarakhand, India," Geomorphology, vol. 193, pp. 8190, 2013.

[73] G. Philip, N. Suresh, and S. S. Bhakuni, "Active tectonics in the northwestern outer Himalaya: evidence of large-magnitude palaeoearthquakes in Pinjaur Dun and the Frontal Himalaya," Current Science, vol. 106, no. 2, pp. 211-222, 2014.

[74] M. Ponraj, S. Miura, C. D. Reddy, S. K. Prajapati, S. Amirtharaj, and S. H. Mahajan, "Estimation of strain distribution using GPS measurements in the Kumaun region of Lesser Himalaya," Journal of Asian Earth Sciences, vol. 39, no. 6, pp. 658-667, 2010.

[75] R. K. Dumka, B. S. Kotlia, K. Kumar, G. S. Satyal, and L. M. Joshi, "Crustal deformation revealed by GPS in Kumaun Himalaya, India," Journal of Mountain Science, vol. 11, no. 1, pp. 41-50, 2014.

[76] R. K. Dumka, B. S. Kotlia, K. Kumar, and G. S. Satyal, "Quantification of crustal strain rate in Kumaun Himalaya (India) using GPS measurements of crustal deformation," Himalayan Geology, vol. 35, no. 2, pp. 146-155, 2014.

[77] F. H. R. Bezerra, D. F. Rossetti, R. G. Oliveira et al., "Neotectonic reactivation of shear zones and implications for faulting style and geometry in the continental margin of NE Brazil," Tectonophysics, vol. 614, pp. 78-90, 2014.

[78] R. H. Sibson, "Fault rocks and fault mechanisms," Journal of the Geological Society, vol. 133, no. 3, pp. 191-213, 1977.

[79] S. Hanmer, "Great Slave Lake Shear Zone, Canadian Shield: reconstructed vertical profile of a crustal-scale fault zone," Tectonophysics, vol. 149, no. 3-4, pp. 245-264, 1988.

[80] R. J. Norris, "Strain localisation within ductile shear zones beneath active faults: the Alpine Fault contrasted with the adjacent Otago fault system, New Zealand," Earth, Planets and Space, vol. 56, no. 12, pp. 1095-1101, 2004. 

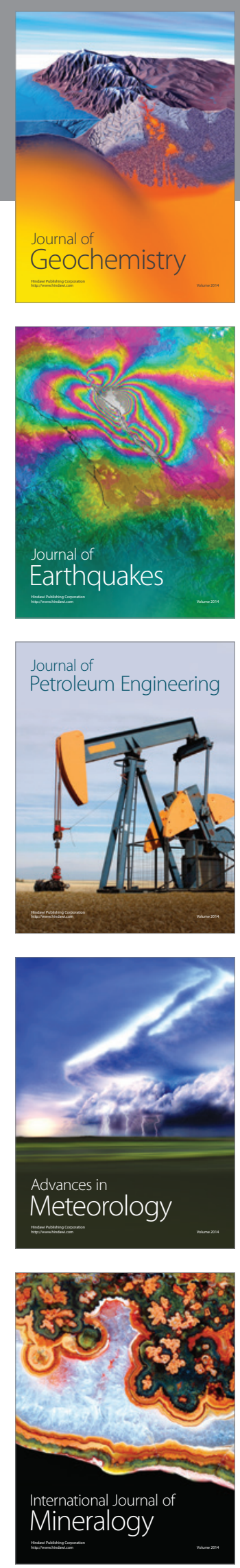
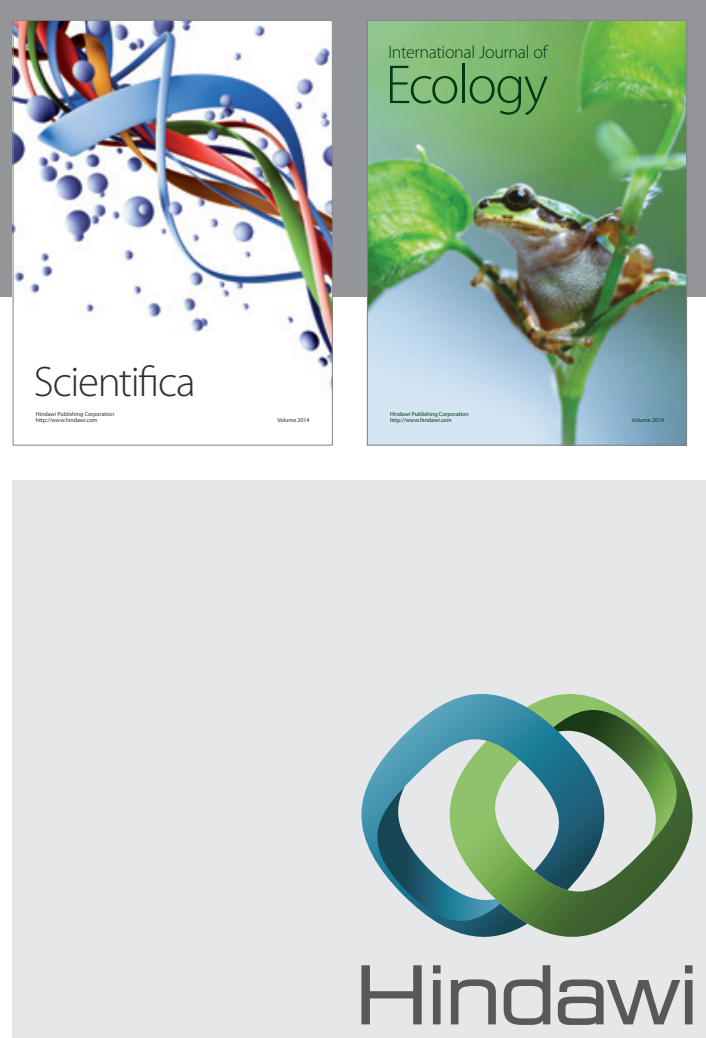

Submit your manuscripts at

http://www.hindawi.com
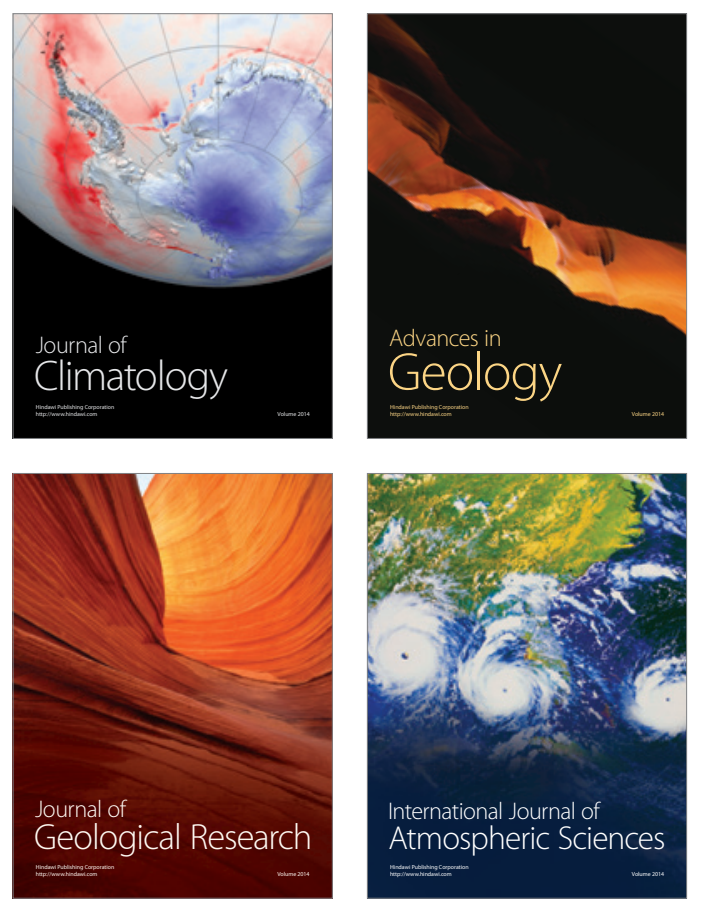

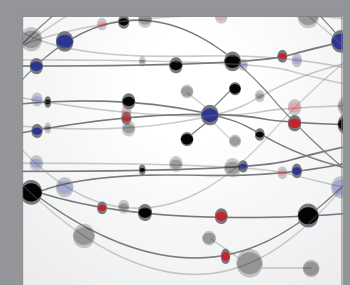

The Scientific

\section{World Journal}
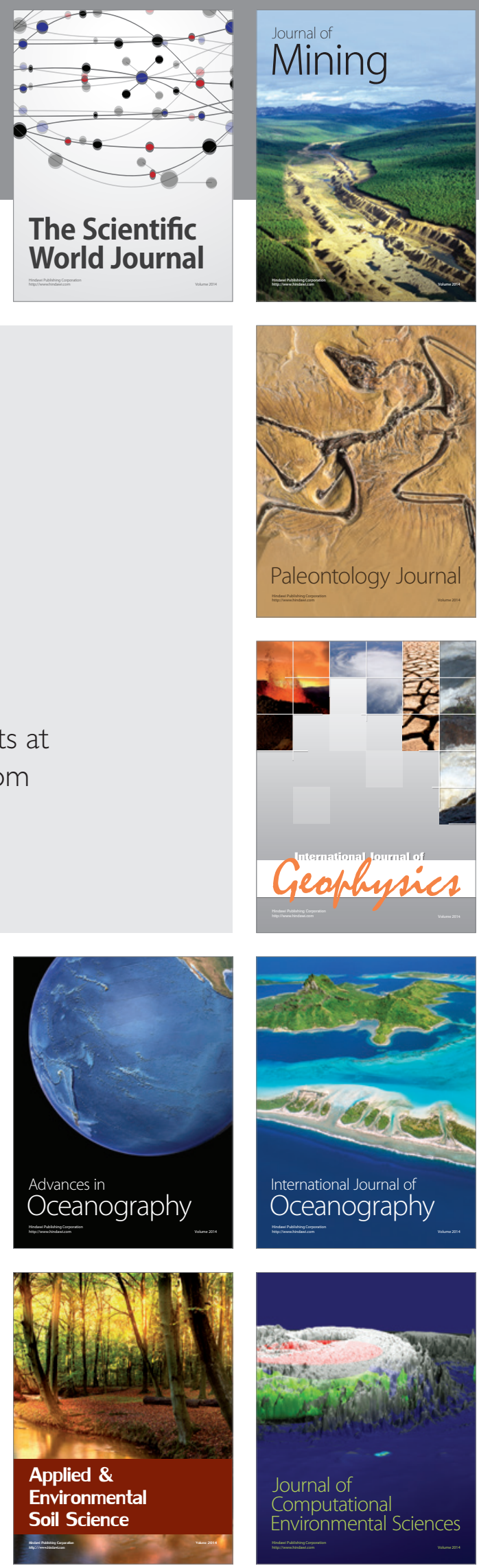